\title{
Extracting and Analyzing Pyrrolizidine Alkaloids in Medicinal Plants: A Review
}

\author{
Thomas Kopp ${ }^{1,2}$, Mona Abdel-Tawab ${ }^{2}$ (D) and Boris Mizaikoff ${ }^{1, *}$ \\ 1 Department of Chemistry, Institute of Analytical and Bioanalytical Chemistry, Ulm University, \\ 89081 Ulm, Germany; Kopp.Thomas1984@gmx.de \\ 2 Central Laboratory of German Pharmacists, 65760 Eschborn, Germany; m.tawab@zentrallabor.com \\ * Correspondence: boris.mizaikoff@uni-ulm.de; Tel.: +49-731-50-22750
}

Received: 4 April 2020; Accepted: 5 May 2020; Published: 13 May 2020

\begin{abstract}
Pyrrolizidine alkaloids (PAs) are distributed in plant families of Asteraceae, Boraginaceae, and Fabaceae and serve in the chemical defense mechanism against herbivores. However, they became a matter of concern due to their toxicity associated with the high risk of intake within herbal preparations, e.g., phytopharmaceutical formulations, medicinal teas, or other plant-derived drug products. In 1992, the German Federal Ministry of Health established the first limits of PA content for fourteen medicinal plants. Because of the toxic effects of PAs, the Federal Institute of Risk Assessment (BfR) established more stringent limits in 2011, whereby a daily intake $<0.007 \mu \mathrm{g} / \mathrm{kg}$ body weight was recommended and valid until 2018. A threefold higher limit was then advised by BfR. To address consumer safety, there is the need for more efficient extraction procedures along with robust, selective, and sensitive analytical methods to address these concerns. With the increased prevalence of, e.g., phytopharmaceutical formulations, this timely review comprehensively focuses on the most relevant extraction and analysis strategies for each of those fourteen plant genera. While a variety of extraction procedures has been reported, differences in PA content of up to $1110 \mathrm{ppm}$ $(0.11 \%(w / w))$ were obtained dependent on the nature of the solvent and the applied extraction technique. It is evident that the efficient extraction of PAs requires further improvements or at least standardization of the extraction conditions. Comparing the various analytical techniques applied regarding selectivity and sensitivity, LC-MS methods appear most suited. This review shows that both standardized extraction and sensitive determination of PAs is required for achieving appropriate safety levels concerning public health in future.
\end{abstract}

Keywords: pyrrolizidine alkaloids; analytical techniques; extraction techniques; medicinal plants; Symphytum; Tussilago; Senecio

Key Contribution: The determined pyrrolizidine alkaloid content in plant extracts depends strongly on the boundary conditions of the extraction procedure; and requires careful analytical strategies for the quantitative assessment of efficiency of the applied procedures

\section{Introduction}

Pyrrolizidine alkaloids (PAs) are secondary plant constituents produced by a wide variety of plants (Asteraceae, Boraginaceae, and Fabaceae) [1,2]. More than 500 different PAs were identified in more than 6000 plant species to date [2]. They are believed to function against herbivores due to the proven inhibiting effect of some PAs on acetylcholinesterase activity [3-6]. Recently, PAs and their corresponding N-oxides (PANs) have been discussed controversially due to their various toxic effects, induced by metabolic activation, resulting in tumors and necrosis of tissue [1,7-10]. The first limits were set in 1992 by the German Federal Ministry of Health addressing pharmaceutical products containing 
herbal preparations of PA producing plants. In more detail, herbs of the genera Symphytum, Borago, Brachyglottis, Cineraria, Alkanna, Tussilago, Lithospermum, Cynoglossum, Senecio, Eupatorium, Anchusa, Petasites, Heliotropium, and Erechthites [11] were concerned. It was proposed that exposure may not exceed $1 \mu \mathrm{g} /$ day during a time period of six weeks. In case of longer usage, this level was further reduced to $0.1 \mu \mathrm{g} / \mathrm{day}$. PA contents which lead to an increased exposure $(10 \mu \mathrm{g} / \mathrm{day})$ were accepted for herbal infusions or decoctions of Tussilago farfara. However, the high risk for ingesting these toxic substances was determined to not only originate from PA-producing medicinal plants. Herbal preparations may be contaminated with weeds as a result of disregardful harvesting or insufficient removal during further processing. Due to the risk of intake and the high toxicity, the Federal Institute of Risk Assessment in Germany (BfR) recommended a daily intake of not more than $0.007 \mu \mathrm{g} / \mathrm{kg}$ body weight (i.e., $0.42 \mu \mathrm{g}$ for a $60 \mathrm{~kg}$ human) [2] in 2011. With respect to the limit stated by German Health Authority in $1992(1 \mu \mathrm{g} /$ day $)$, this correspond to a 50\% lower threshold. New risk assessments of European Food Safety Agency (EFSA) and BfR were based on the NTP study on riddelliine rather than the one on lasiocarpine and derived a threefold higher reference point of $237 \mu \mathrm{g} / \mathrm{kg} \mathrm{bw} /$ day. This effectively means that an exposure lower than $0.0237 \mu \mathrm{g} / \mathrm{kg} \mathrm{bw} /$ day is considered a low health concern (margin of exposure larger than 10,000) $[12,13]$. Especially for the required detection of the low levels of PAs, more efficient extraction methods along with selective and sensitive analytical strategies are essential.

This review is dedicated to summarizing the scientific progress within approximately 30 years of research in PA extraction and analysis of medicinal plants. For each of them, we summarize the most prevalent extraction techniques and analytical methods used for determining their concentration levels. Parameters such as increased extraction temperatures, fresh solvent, high pressure, and a large surface area are compared for promoting efficient extraction. Analytical methods are rated according the reported selectivity of the procedure and the analytical-figures-of-merit with special emphasis on the sensitivity (LoD and LoQ). Additionally, whenever reasonable, the potential advantages and disadvantages of the analytical method are outlined.

\section{Design and Methods}

A systematic literature research was performed using the Mendeley online database (www. mendeley.com). Keywords for the search were "plant genus + pyrrolizidine" or "plant genus + medicinal use"; for example, "Senecio + pyrrolizidine" or "Senecio + medicinal use". All published manuscripts regarding extraction or analysis of PAs were reviewed. Results were not filtered by year or language. Published literature was considered if extractions or analytical studies were performed on one of the thirteen medicinal plant genera of interest that have been defined by the German Federal Ministry of Health. Finally, more than 225 papers were considered for this review.

\section{Considered Medicinal Plants}

The German Federal Ministry of Health, addressed in 1992 the admission and registration of herbal preparations containing PAs [11]. Fourteen plants were considered to be of phytopharmaceutical relevance. These plants were reviewed for the extraction and analytical methods applied. Except the genus Erechthites, all other genera were represented in scientific literature. Examples of inherent PAs are shown in Figures 1-3. Because of the large number of species that have been partly investigated and the differences in the PA composition depending on the growth conditions and time of investigations of the individual species, only the genera are cited. 


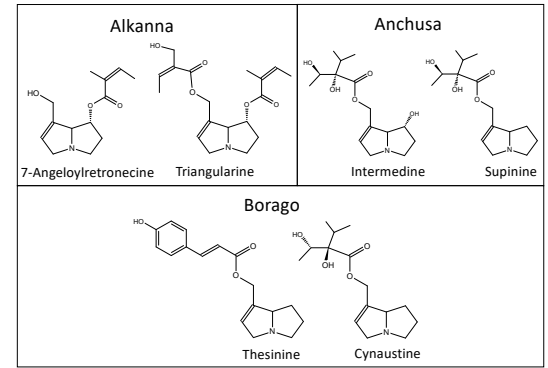

Figure 1. Pyrrolizidine alkaloids inherent in the genera of Alkanna, Anchusa, and Borago.

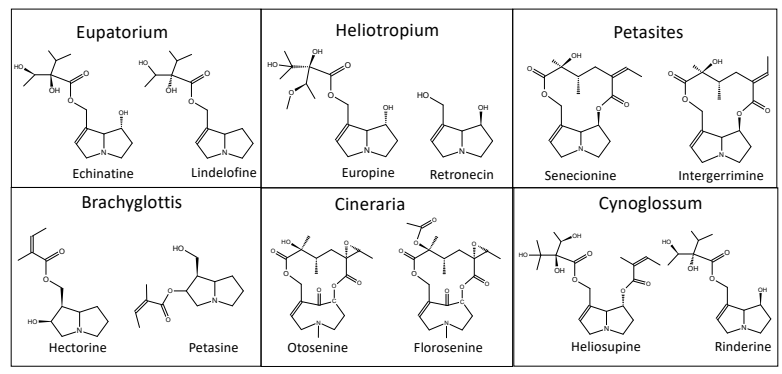

Figure 2. Examples for PAs inherent in plants of the genera Eupatorium, Heliotropium, Petasites, Brachyglottis, Cineraria, and Cynoglossum.

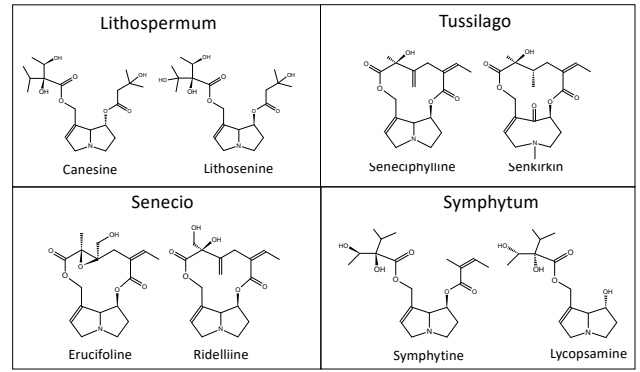

Figure 3. Pyrrolizidine alkaloids inherent in plants of the genera Lithospermum, Tussilago, Senecio, and Symphytum.

\section{Extraction, and Analytical Techniques}

Various techniques for extraction (see Table 1) of pyrrolizidine alkaloids from medicinal plants (see Table 2) are discussed. While some of them are more commonly used than others, most of them are based on maceration or percolation, the two main extraction principles stated in the literature (see Table 3). During maceration, the sample is soaked continuously with solvent, whereas, during percolation, the solvent flows through the plant material. Due to the dependence of the extraction yield on parameters such as viscosity of the solvent, diffusion coefficient and sample penetration, the technical implementation and the physical conditions vary.

After successful extraction, sample solutions were most commonly analyzed using chromatographic separation techniques such as HPLC, TLC and GC coupled with various detection methods. Capillary electrophoresis (CE) with the separation based on migration of molecules in an electric field, droplet counter current chromatography (DCCC) serving as an automated liquid-liquid separation method, and miscellaneous electrokinetic chromatography (MEKC) techniques, which are based on a combination of electrophoretic and chromatographic principles, were used as well. Additionally, specific techniques without prior separation or purification such as ${ }^{1} \mathrm{H}-\mathrm{NMR},{ }^{13} \mathrm{C}-\mathrm{NMR}$, or ELISA (Enzyme Linked Immunosorbent Assay) tests based on specific antibody interactions with the target molecule were used for quantification. An overview of the separation and detection techniques is given in Table 4 . 
Table 1. Concise description of extraction techniques used. All technical variations are based on maceration or percolation.

\begin{tabular}{|c|c|c|c|c|c|}
\hline Technique & Temperature & Pressure & Sample & Solvent & Remarks \\
\hline Maceration & $\leq$ boiling point & atmospheric & e.g., flask & any solvent & sample is extracted by soaking in solvent \\
\hline Refluxing & $\leq$ boiling point & atmospheric & $\begin{array}{l}\text { round bottomed } \\
\text { flask }\end{array}$ & any solvent & $\begin{array}{l}\text { maceration on increased temperature, } \\
\text { vaporization of solvent is avoided by } \\
\text { condensation }\end{array}$ \\
\hline Soxhlet & $\leq$ boiling point & atmospheric & Soxhlet cartridge & any solvent & special form of percolation (continuous) \\
\hline Percolation & room temperature & atmospheric & e.g., column & any solvent & $\begin{array}{c}\text { sample placed in column, solvent is added, flow } \\
\text { through and is released }\end{array}$ \\
\hline Sonication & room temperature & atmospheric & e.g., flask & any solvent & $\begin{array}{c}\text { maceration assisted by sonication to increase } \\
\text { solubility }\end{array}$ \\
\hline $\begin{array}{l}\text { SFE (Supercritical Fluid } \\
\text { Extraction) }\end{array}$ & $>$ boiling point & pressurized & reaction vessel & e.g., $\mathrm{CO}_{2}$ & $\begin{array}{l}\text { temperature and pressure above critical point to } \\
\text { control extraction characteristics }\end{array}$ \\
\hline $\begin{array}{l}\text { PLE (Pressurized Liquid } \\
\text { Extraction) }\end{array}$ & $>$ boiling point & pressurized & reaction vessel & $\begin{array}{l}\text { no } \\
\text { corrosive/decomposing } \\
\text { solvents }\end{array}$ & $\begin{array}{l}\text { pressurization allows temperatures above boiling } \\
\text { point, faster extractions }\end{array}$ \\
\hline $\begin{array}{l}\text { MAE (Microwave } \\
\text { Assisted Extraction) }\end{array}$ & $>$ boiling point & atmospheric & reaction vessel & $\begin{array}{l}\text { no decomposing } \\
\text { solvents }\end{array}$ & $\begin{array}{l}\text { pressurization or pressure stabile reaction vessels } \\
\text { allow temperatures above boiling point, faster } \\
\text { extractions heated by radiation }\end{array}$ \\
\hline $\begin{array}{l}\text { HPPE (High Pressure } \\
\text { Propane Extraction) }\end{array}$ & $>$ boiling point & pressurized & reaction vessel & propane & variation of SFE \\
\hline Cold Ion Exchange & room temperature & atmospheric & column & any solvent & $\begin{array}{l}\text { plant material placed in column solvent is } \\
\text { pumped continues in cycle, analyte is adsorbed on } \\
\text { specific material }\end{array}$ \\
\hline $\begin{array}{l}\text { PHWE (Pressurized Hot } \\
\text { Water Extraction) }\end{array}$ & $>$ boiling point & pressurized & column & $\begin{array}{l}\text { water (different } \\
\text { modifier) }\end{array}$ & $\begin{array}{l}\text { sample is placed in column, hot water (modifier) } \\
\text { is pumped through column }\end{array}$ \\
\hline
\end{tabular}


Table 2. Overview of PAs detected and identified in different genera. No distinction between N-oxides and free bases is made, as this was not differentiated by all research groups. The main name describes the PA and its derivatives.

\begin{tabular}{|c|c|}
\hline Genus & Identified PAs \\
\hline $\begin{array}{c}\text { Alkanna } \\
\text { (Boraginaceae) }\end{array}$ & $\begin{array}{c}\text { 7-Angeloylretronecine [14,15], 9-Angeloylretronecine [14], 7-Tigloylretronecine [14], 7-Senecioylretronecine [14], 9-Tigloylretronecine [14], } \\
\text { 9-Senecioylretronecine [14], 7-Angeloyol-9-(hydroxypropenoyl) retronecine [14], 7-Tigloyl-9-(hydroxy propenoyl) retronecine [14], } \\
\text { 7-Angeloyol-9-(2,3-dihydroxypropanoyl) retronecine [14], 7-Tigloyl-9-(2,3-dihydroxypropanoyl) retronecine [14], Triangularine [14,15], } \\
\text { Triangularicine [14], Dihydroxytriangularicine [14,15] }\end{array}$ \\
\hline $\begin{array}{c}\text { Anchusa } \\
\text { (Boraginaceae) }\end{array}$ & Anthamidin [14], Supinine [14,16], Intermedin [14,16], Lycopsamine [14,16], Currassavine [16] \\
\hline $\begin{array}{c}\text { Borago } \\
\text { (Boraginaceae) }\end{array}$ & Lycopsamine [17], Supinidine [17],Viridiflorate [17], Cynaustine [17], Amabaline [17,18], Thesinine [18,19] \\
\hline $\begin{array}{l}\text { Brachyglottis } \\
\text { (Asteraceae) }\end{array}$ & Senecionine [20,21], Retrorsine [20,21], Integerrimine [20], Senkirkine [20], Hectorine [20,21], Petasin [20,21], Angeloylheliotridine [20], Clivorine [20] \\
\hline $\begin{array}{c}\text { Cineraria } \\
\text { (Asteraceae) }\end{array}$ & $\begin{array}{c}\text { Otosenine [22,23], Florosenine [22,23], Floridanine [22,23], Doronine [22], Senecionine [23,24], Integerrimine [23,24], Seneciphylline [23,24], Jacobine } \\
\text { [23,24], Usaramine [23] }\end{array}$ \\
\hline $\begin{array}{l}\text { Cynoglossum } \\
\text { (Boraginaceae) }\end{array}$ & Heliosupine [25,26], Rinderine [25,26] Echinatine [25,26], Viridiflorine [26] \\
\hline $\begin{array}{l}\text { Eupatorium } \\
\text { (Asteraceae) }\end{array}$ & $\begin{array}{c}\text { Lindelofine [27], Supinine [27-30], Lycopsamine [30-32], Intermedin [30-32], Amabaline [28,33], Echinatine [28-30,32,33], Rinderine [28], } \\
\text { Viridiflorine [28], Cynaustraline [28], Tussilagine [34] }\end{array}$ \\
\hline $\begin{array}{l}\text { Heliotropium } \\
\text { (Boraginaceae) }\end{array}$ & $\begin{array}{c}\text { Trachelanthamine [35,36], Floridine [35], Heliovicine [35], Lycopsamine [37,38], Intermedin [38], Amabiline [37], Curassavine [37,39], Heliospathine } \\
\text { [37], Europine [40-43], Liamin [40], Heliotrine [42-45], Lasiocarpine [42,45,46], Retronecine [38,47-49], Helibracteatine [47], Helifoline [48], } \\
\text { Heliscabine [49], Heliosupine [44,46], Echinatine [44], Supinine [43], Heleurine [43], Coromandaline [39] }\end{array}$ \\
\hline $\begin{array}{l}\text { Lithospermum } \\
\text { (Boraginaceae) }\end{array}$ & Lithosenine [50], Lycopsamine [51], Canescine [51,52] derivatives, Canescinine [51], Intermedine [51,53], Mysocorpine [53] \\
\hline $\begin{array}{c}\text { Petasites } \\
\text { (Asteraceae) }\end{array}$ & Senkirkine [54-56], Senecionine [54,56-59], Intergerrimine [58,59], Petasitenine [55], Neopetasitenine [55] \\
\hline $\begin{array}{c}\text { Senecio } \\
\text { (Asteraceae) }\end{array}$ & $\begin{array}{c}\text { Ridelline [60-66], Retrorsine [60-85], Seneciphylline [60-68,70-72,75,77,78,80-84,86-99], Senecionine [60-71,73-84,86,87,89-101],Senkirkine } \\
\text { [60-62,65,68,73,74,77,79,80,83,89,97,98,101], Jacobine [68,78,82,87,91,94-96,99], Integerrimine [61-64,66,68-80,82-84,87,89,92-95,97,99-101], } \\
\text { Spartiodine [61-63,66,68,70,77,78,82,90,92], Senecivernine [62,63,66,68,69,71,73-78,80,82,87,94,97], Platyphylline [61,62,100,102,103], Usaramine } \\
\text { [61,63,66,68-71,73,74,77-79], Adinofoline [61,68,104], Florosenine [68,71,73,74,77,94,98,101], Erucifoline [68,83,87,94,95], Otosenine } \\
\text { [68,71,73,74,77,88,94,97,101], Triangularine [75,100,105], Sarracine [75,100,105], Sarracinine [100], Eruciflorine [68,87], Onetine [68], Floridanine [68], } \\
\text { Senecicannabine [68,106], 7-Angeloylheliotridine [97,103], 9-Tiglylplatynecine [75,100], 7-Angeloylretronecine [75,97], Petasin [97], } \\
\text { 9-Angeloylplatynecine [75], Monocrotaline [65], Uspallatine [69,85], Rosmarinine [90,107,108], Angularine [107,108], Hadiensiene [107], Ruwenine } \\
\text { [109], Ruzorine [109], Doriasenine [110], Sceleratine [111] }\end{array}$ \\
\hline $\begin{array}{c}\text { Symphytum } \\
\text { (Boraginaceae) }\end{array}$ & Echimidine [112-114], Symphytine [112,113], Lasiocarpine [64], Intermedin [115], Lycopsamine [114-116] \\
\hline $\begin{array}{c}\text { Tussilago } \\
\text { (Asteraceae) }\end{array}$ & Senkirkine [117-120], Senecionine [116,118-121], Intergerrimine [120], Seneciphylline [120], Senecivernine [122] \\
\hline
\end{tabular}


Table 3. Overview of the extraction techniques and solvents used to process plant extracts.

\begin{tabular}{|c|c|c|}
\hline Genus & Technique & Solvent \\
\hline $\begin{array}{c}\text { Alkanna } \\
\text { (Boraginaceae) }\end{array}$ & Maceration & $0.5 \mathrm{~N} \mathrm{HCl}$ [14], Methanol [15] \\
\hline $\begin{array}{c}\text { Anchusa } \\
\text { (Boraginaceae) }\end{array}$ & Maceration & $0.5 \mathrm{~N} \mathrm{HCl}$ [14], Chloroform [123,124], Methanol [123,124], Methanol/Water/Formic Acid (25/2/73) [125] \\
\hline \multirow{2}{*}{$\begin{array}{c}\text { Borago } \\
\text { (Boraginaceae) }\end{array}$} & Maceration & Methanol/Water/Formic Acid (25/2/73) [125], Methanol/Water [126], Hexane [18] \\
\hline & Refluxing & Methanol/Water (4:1) [19] \\
\hline $\begin{array}{l}\text { Brachyglottis } \\
\text { (Asteraceae) }\end{array}$ & Maceration & Methanol [21], Ethanol [20] \\
\hline $\begin{array}{c}\text { Cineraria } \\
\text { (Asteraceae) }\end{array}$ & Maceration & Methanol [22,24], $0.5 \mathrm{~N} \mathrm{HCl}[23]$ \\
\hline \multirow{3}{*}{$\begin{array}{l}\text { Cynoglossum } \\
\text { (Boraginaceae) }\end{array}$} & Maceration & 0.5 M Sulfuric Acid [127,128], Methanol [129], 0.5M HCl [26] \\
\hline & Soxhlet & Methanol $[25,130]$ \\
\hline & Refluxing & Tartaric Acid in Methanol [131] \\
\hline \multirow{3}{*}{$\begin{array}{l}\text { Eupatorium } \\
\text { (Asteraceae) }\end{array}$} & Maceration & Methanol [27,29-31], Water [31], 0.05 M Sulfuric Acid [32] \\
\hline & Soxhlet & Methanol/Dichlormethane [34] \\
\hline & Percolation & Ethanol [33] \\
\hline \multirow{3}{*}{$\begin{array}{l}\text { Heliotropium } \\
\text { (Boraginaceae) }\end{array}$} & Maceration & Methanol [36,37,39,45,46,132], Ethanol [35,38,43,133-135], Methanol/Water/Formic Acid (25/23/2) [125] \\
\hline & Percolation & Methanol [40-42], Ethanol $[39,47,49,136]$ \\
\hline & Refluxing & Methanol [137] \\
\hline \multirow{3}{*}{$\begin{array}{l}\text { Lithospermum } \\
\text { (Boraginaceae) }\end{array}$} & Soxhlet & Methanol $[50,51,53]$ \\
\hline & Refluxing & Tartaric Acid in Methanol [131] \\
\hline & Sonication & Methanol [52] \\
\hline \multirow{5}{*}{$\begin{array}{c}\text { Petasites } \\
\text { (Asteraceae) }\end{array}$} & Maceration & Methanol [57,59,93], Water [55] \\
\hline & Refluxing & Methanol/Tartaric Acid [54] \\
\hline & Soxhlet & Ethanol [55] \\
\hline & SFE & $\mathrm{CO}_{2}[138]$ \\
\hline & HP-Propan & Propane [139] \\
\hline
\end{tabular}


Table 3. Cont

\begin{tabular}{|c|c|c|}
\hline Genus & Technique & Solvent \\
\hline \multirow{7}{*}{$\begin{array}{c}\text { Senecio } \\
\text { (Asteraceae) }\end{array}$} & Maceration & $\begin{array}{l}\text { 0.05 M Sulfuric Acid [72], } 1 \text { M Sulfuric Acid [63], 0.05 M Hydrochloric Acid [140], 0.1 M Hydrochloric Acid [92], } 1 \mathrm{M} \\
\text { Hydrochloric Acid [68], Chloroform 0.1 M Hydrochloric Acid (1:1) [73], Methanol [64,69,75,85,90,97,106,140-143], Ethanol } \\
\text { [79,84,107,144-146], 0.4 M Formic Acid [66], Et2O/Pertolum Ether/Methanol (1:1:1) [98], 0.05 M Sulfuric Acid [72] }\end{array}$ \\
\hline & Refluxing & Methanol [86,91,93], Ethanol [61] \\
\hline & Soxhlet & Methanol $[71,74,76,82,83,86,91,96,99,100,103,107,108,147-151]$ \\
\hline & Sonication & 0.05 M Hydrochloric Acid \\
\hline & SFE & $\mathrm{CO}_{2}[78]$ \\
\hline & PLE & Sulfuric Acid [122], Phosphoric Acid [122], Ammonia [122], Acetic Acid [122], Formic Acid [122] \\
\hline & $\begin{array}{l}\text { Cold Ion } \\
\text { Exchange/ } \\
\text { Continuous } \\
\text { Extractor }\end{array}$ & Methanol [81], Petroleum Ether [101] \\
\hline \multirow{6}{*}{$\begin{array}{l}\text { Symphytum } \\
\text { (Boraginaceae) }\end{array}$} & Maceration & $\begin{array}{c}\text { Methanol (hot) [93], Methanol [64,152], 0.025 M Sulfuric Acid [153], Water (hot) [154], Tartaric acid in Methanol [152]; Ethanol } \\
\text { [152] 0.7 M HCl [152], Chloroform/Methanol [152] }\end{array}$ \\
\hline & Refluxing & $\begin{array}{c}\text { Tartaric Acid in Methanol [54,152], Methanol/Water (50/50) [116], Ethanol [152], } 0.7 \mathrm{M} \mathrm{HCl} \mathrm{[152],} \mathrm{Ascorbic} \mathrm{Acid} \mathrm{in} \mathrm{Methanol} \\
\text { [152] }\end{array}$ \\
\hline & Sonication & $\begin{array}{c}\text { Chloroform (basic) [155], Methanol/Water (50/50) [116], Methanol/Chloroform (15/85) [116], Methanol [116], Ethanol [116], } \\
\text { Tartaric Acid in Methanol [152], Acetic Acid [152] }\end{array}$ \\
\hline & Percolation & Methanol [152] \\
\hline & HWPE & Water [116] \\
\hline & PLE & Acetic Acid [122], Phosphoric Acid [122], Formic Acid [122], Sulfuric Acid [122], Ammonia [122] \\
\hline \multirow{6}{*}{$\begin{array}{c}\text { Tussilago } \\
\text { (Asteraceae) }\end{array}$} & Maceration & Methanol/Citric Acid [118,119,121], Methanol/Ammonia [118], 0.25 M Sulfuric Acid [156], Water [118], Acidified Water [118] \\
\hline & Microwave & Methanol/Water acidified with hydrochloric acid or acetic acid [157] \\
\hline & Refluxing & Methanol/Tartaric acid [117], Water [54,118], Methanol alkaline [118], $1 \mathrm{M} \mathrm{HCl} \mathrm{[157]}$ \\
\hline & Soxhlet & Methanol [118] \\
\hline & PHWE & Hot water [157] \\
\hline & PLE & Acetic acid [122], Phosphoric acid [122], Formic acid [122], Sulfuric acid [122], Ammonia [122] \\
\hline
\end{tabular}


Table 4. Overview of analytical techniques and detection methods for the determination of PAs in plant extracts. The LoD or LoQ is listed if given in corresponding manuscript, if not it is characterized by " - ".

\begin{tabular}{|c|c|c|c|c|}
\hline Genus & Separation & Detection & LoD (ppm) & LoQ (ppm) \\
\hline \multirow{2}{*}{$\begin{array}{c}\text { Alkanna } \\
\text { (Boraginaceae) }\end{array}$} & GC & MS [14] & - & - \\
\hline & DCCC & UV [15] & - & - \\
\hline \multirow{2}{*}{$\begin{array}{c}\text { Anchusa } \\
\text { (Boraginaceae) }\end{array}$} & GC & MS $[14,16]$ & - & - \\
\hline & HPLC & MS [124,125] & - & - \\
\hline \multirow{5}{*}{$\begin{array}{c}\text { Borago } \\
\text { (Boraginaceae) }\end{array}$} & GC & MS $[18,19]$ & - & - \\
\hline & HPLC & MS [126] & - & - \\
\hline & HPLC & MS/MS [125] & - & - \\
\hline & HPLC & Orbitrap $[125,126]$ & - & 0.325 \\
\hline & TLC & Ehrlichs Reagent [17] & & \\
\hline \multirow{2}{*}{$\begin{array}{l}\text { Brachyglottis } \\
\text { (Asteraceae) }\end{array}$} & GC & MS $[20,21]$ & - & - \\
\hline & TLC & Visual $[20,21]$ & - & - \\
\hline $\begin{array}{c}\text { Cineraria } \\
\text { (Asteraceae) }\end{array}$ & GC & MS [14,22] & - & - \\
\hline \multirow{5}{*}{$\begin{array}{l}\text { Cynoglossum } \\
\text { (Boraginaceae) }\end{array}$} & HPLC & MS $[25,131]$ & - & - \\
\hline & GC & MS $[26,129,158]$ & - & - \\
\hline & TLC & Visual $[25,158]$ & - & - \\
\hline & none & Photometric [127-129] & - & - \\
\hline & none & q-NMR [130] & - & - \\
\hline \multirow{3}{*}{$\begin{array}{l}\text { Eupatorium } \\
\text { (Asteraceae) }\end{array}$} & HPLC & MS/MS $[31,32]$ & - & - \\
\hline & GC & MS [28,30,34,159] & - & - \\
\hline & TLC & Visual [27,29,33], Chloranillin [30], Mattocks Reagent [34] & - & - \\
\hline \multirow{5}{*}{$\begin{array}{l}\text { Heliotropium } \\
\text { (Boraginaceae) }\end{array}$} & HPLC & MS/MS [125] & - & - \\
\hline & GC & MS $[45,135,137,160]$ & - & - \\
\hline & None & p-Toluene Sulfonic Acid [137] & - & - \\
\hline & TLC & Dragendorffs [137] & - & - \\
\hline & None & Photometric [137] & - & - \\
\hline
\end{tabular}


Table 4. Cont

\begin{tabular}{|c|c|c|c|c|}
\hline Genus & Separation & Detection & LoD (ppm) & LoQ (ppm) \\
\hline \multirow{4}{*}{$\begin{array}{l}\text { Lithospermum } \\
\text { (Boraginaceae) }\end{array}$} & GC & MS [50-52,131] & - & - \\
\hline & HPLC & DAD [131] & - & - \\
\hline & HPLC & MS [131] & - & - \\
\hline & TLC & Ehrlichs-Reagent [52] & - & - \\
\hline \multirow{9}{*}{ Petasites (Asteraceae) } & HPLC & UV [54-56,161] & $0.10-5.0$ & $0.35-25.0$ \\
\hline & HPLC & RI [55] & - & $<10$ \\
\hline & HPLC & ToF-MS [56,161] & 0.01 & 0.50 \\
\hline & UPLC & ToF-MS [138] & - & 0.002 \\
\hline & GC & FID [93] & 2 & - \\
\hline & TLC & Densiometric [54] & 20 & 40 \\
\hline & TLC & UV [57] & 1 & - \\
\hline & None & Photometric [162] & - & - \\
\hline & None & ELISA [57-59] & 0.10 & - \\
\hline \multirow{12}{*}{ Senecio (Asteraceae) } & GC & FID $[68,72,77,78,82,84,87,95,99]$ & - & - \\
\hline & GC & MS $[62,63,67,68,73-77,83,84,87,92,94,99,103,147]$ & - & - \\
\hline & GC & NPD $[68,72,87]$ & - & - \\
\hline & GC & FTIR [71], & - & - \\
\hline & HPLC & UV $[140,151]$ & $0.13 \times 10^{-3}-0.31 \times 10^{-3}$ & - \\
\hline & HPLC & ELSD [64] & 40 & - \\
\hline & HPLC & MS $[86,150]$ & - & - \\
\hline & HPLC & MS/MS $[66,96,104]$ & $0.5 \times 10^{-3}$ & $1.0 \times 10^{-3}$ \\
\hline & UHPLC & DAD-MS [61] & - & - \\
\hline & UHPLC & MS/MS [65] & $0.3 \times 10^{-6}-11 \times 10^{-6}$ & $0.8 \times 10^{-3}-36 \times 10^{-3}$ \\
\hline & None & ELISA [141,163-165] & $0.02 \times 10^{-3}-10,000 \times 10^{-3}$ & - \\
\hline & None & q-NMR $(1 \mathrm{H} / 13 \mathrm{C})[80,149,166,167]$ & - & - \\
\hline
\end{tabular}


Table 4. Cont

\begin{tabular}{|c|c|c|c|c|}
\hline Genus & Separation & Detection & LoD (ppm) & LoQ (ppm) \\
\hline \multirow{11}{*}{$\begin{array}{c}\text { Symphytum } \\
\text { (Boraginaceae) }\end{array}$} & HPLC & DAD [54] & $0.06-0.2$ & $0.10-0.35$ \\
\hline & HPLC & ELSD [64] & 40 & - \\
\hline & HPLC & MS [116] & - & - \\
\hline & HPLC & MS/MS [122] & $1 \times 10-3$ & $5 \times 10^{-3}$ \\
\hline & GC & FID $[93,114]$ & - & - \\
\hline & GC & MS [114,153] & - & - \\
\hline & GC & NPD [154] & $0.4 \times 10-3-1.0 \times 10-3$ & - \\
\hline & GC & FTIR [115] & - & - \\
\hline & TLC & Densiometric $[54,168]$ & 22 & 73 \\
\hline & TLC & Visual [154] & - & - \\
\hline & None & Photometric $[152,169]$ & 1 & - \\
\hline \multirow{9}{*}{$\begin{array}{c}\text { Tussilago } \\
\text { (Asteraceae) }\end{array}$} & HPLC & UV [170] & - & - \\
\hline & HPLC & Q-ToF [117] & $0.275 \times 10-3$ & $0.916 \times 10^{-3}$ \\
\hline & HPLC & MS/MS [122,171] & $<1.0 \times 10-3$ & $<5.0 \times 10^{-3}$ \\
\hline & HPLC & MS/MS [157] & $0.26-1.32$ & $1.04-5.29$ \\
\hline & $\mathrm{CE}$ & UV [118] & $<0.1 \times 10-3$ & - \\
\hline & MEKC & UV [121] & $2.0 \times 10-3-5.0 \times 10-3$ & - \\
\hline & GC & MS [120] & - & - \\
\hline & TLC & VIS [117] & - & - \\
\hline & Titration & Visually [156] & - & - \\
\hline
\end{tabular}




\section{Results}

Thirteen of the fourteen genera relevant in 1992 are considered in the following sections. The genus Erechtites could ultimately not be considered because of a lack of published data.

\subsection{Alkanna}

The genus Alkanna includes about 50 subtypes. For example, Alkanna tinctorial is used topically for skin treatment due to its antibacterial effects [172]. The PAs found in the genus Alkanna are listed in Table 2. Extraction was done by grinding the plant parts in Ultraturax using $0.5 \mathrm{~N}$ hydrochloric acid as a solvent followed by soaking for $1 \mathrm{~h} \mathrm{[14]}$. Another procedure uses maceration in methanol [15] (see Table 3). Quantitative analysis was performed by GC-MS [14]. Identification or qualitative analysis was performed by ${ }^{13} \mathrm{C}-\mathrm{NMR},{ }^{1} \mathrm{H}-\mathrm{NMR}$, infrared spectroscopy, or mass spectrometry [15] (see Table 4).

\subsection{Anchusa}

This genus includes about 50 species and is used in folk medicine for treating open wounds and cuts [173]. Inherent PAs (see Table 2) were extracted by stepwise maceration with methanol and $\mathrm{CHCl}_{3}[123,124]$ by grinding plant parts in $0.5 \mathrm{~N} \mathrm{HCl}$, as described by El Shazly [14] or using an acidified mixture of methanol, combining the extraction power of organic, aqueous and acidic solvents [125] (see Table 3). Analytical methods (see Table 4) were focused on isolation and identification of the different PAs/PANs predominantly by GC-MS [14,16,124]. Siciliano et al. illustrated the PA pattern in leaves, flowers and roots applying LC-MS. They were able to show that the leaves contain most PAs followed by flowers and roots [123]. These et al. applied the previously reported LC-MS/MS screening method [125].

\subsection{Borago}

Plants of the genus Borago are used in herbal medicinal products due its antihypertensive effect [174], amoebicidal activity to treat gastrointestinal diseases [175], and antioxidant and antimicrobial effects $[176,177]$. PAs determined in the different subtypes are listed in Table 2. Only few studies were devoted to the extraction of Borago (see Table 3). Half of them investigated seeds or its oil [17-19,126], which were processed by dissolving and vortex shaking [125,126] for analysis. Only Hermann et al. refluxed the samples and isolated a glycosylated PA from Borago by further processing [19]. These et al. used $25 \%$ methanol in $2 \%$ formic acid for maceration and reached with their screening method based on tandem MS sensitivities in the low ppb region [125]. Despite the simpler matrix and the usage of an Orbitrap, Vacilotto et al. reached a LoQ of $0.325 \mathrm{ppm}$ for the analysis of PAs in oil [125]. Dodson et al. determined the PAs in different plant parts and seeds with gas chromatography [18]. A similar experiment was done by Larson et al. investigating the PA content of fresh leaves and roots by TLC and visualizing them via Ehrlichs reagent [17].

\subsection{Brachyglottis}

With its 39 species that are all native to New Zeeland, Brachyglottis belongs to the aster family. It is used to treat sores and wounds [178]. Antifungal [179], antiviral [178], anti-microbial [180], and anti-cancer $[178,180]$ properties were studied. Extraction of plant parts (listed in Table 3) was performed by maceration with ethanol [20] or methanol [21]. Inherent PAs are summarized in Table 2. Quantification was carried out via GC-MS [20,21].

\subsection{Cineraria}

Cineraria includes 35 species and is used in traditional medicine due to its abortive, uterus cleaning properties as well as for its potential for treating chickenpox [181]. Tunudis et al., El Shazly et al., and Wiedenfeld et al. investigated the PAs inherent to Cineraria species (see Table 2). They used maceration 
with methanol [22,24] or grinding and soaking [23]. Separation and quantification was performed by GC-MS [22,23] (see Table 4).

\subsection{Cynoglossum}

The genus Cynoglossum shows strong affinity to some of its neighboring genera (e.g., Pardoglossum or Solenanthus) [182,183]. With over 75 species distributed worldwide, it is used in traditional medicine for treating illness with fever, headache and sweating [184]. Moreover, Cynoglossum clumnae revealed to exert cytotoxic [185,186], antimicrobial [185-187], antifungal [185], antidiabetic, antihyperlipidemic, and antioxidant effects [188]. Only a few PAs were identified in the genus Cynoglossum (see Table 2). Extraction was performed with Soxhlet extraction using methanol $[25,130]$ or maceration with ethanol 95\% [158], sulfuric acid $0.5 \mathrm{~N}$ [127,128], methanol [129], or hydrochloric acid $0.5 \mathrm{~N}$ [26]. Mroczek et al. extracted the PAs by refluxing with $1 \%$ tartaric acid in methanol [131]. No research group has to date investigated, optimized, or compared the influence of different extraction conditions on the PA content with the same plant material. The most promising extraction procedures were used by Mroczek et al. based on results achieved for comfrey [131]. Considering these results, there may be losses anticipated during long term extraction at elevated temperatures $[25,127,130]$ because of PA degradation. Mattocks used GC-MS for identification of the different PAs in the genus Cynoglossum [158], while El-Shazly et al. for screening of the alkaloid profiles in stems, leaves, flowers, fruits, and roots [26]. Van Dam et al. quantified the individual PAs with GC-MS [129] before determining the sum with a photometric color-reaction based method [127-129] developed by Mattocks [189]. HPLC-DAD-MS was used for PA screening of different plants too [131]. A screening of different plants during maturation, without further purification, was done by Pfister et al. using q-NMR [130]. Purification or separation without direct quantification was done by TLC $[25,129,158]$.

\subsection{Eupatorium}

In sum, there are over 45 different species of the genus Eupatorium. Different subtypes were investigated due to their pharmaceutical applications based on their antimicrobial [190-192], wound healing [192,193], analgesic [193], anti-inflammatory [192,193], antidiabetic [192], hepatoprotective [192], and antioxidant [192] effects. Echinatine, lycopsamine, and intermedine are the most reported PAs in Eupatorium (see Table 2). Samples are extracted mainly by maceration [27,29-32], percolation [33], or using Soxhlet [34] (see Table 3). Colegate et al. compared qualitatively maceration in methanol over $16 \mathrm{~h}$ at room temperature with hot water infusions or decoctions [31] (see Table 5). Hot water infusions and decoctions lead to high amounts of all PAs [31], whereas alcoholic tinctures mainly contain increased contents of free bases. This underlines that short extractions at high temperatures can result in increased yields of PAs.

Table 5. Overview on the studies by Colegate et al. regarding optimal PA extraction for Eupatorium

[31]. Missing information is characterized by "-".

\begin{tabular}{cccccccc}
\hline Technique & $\begin{array}{c}\text { Sample } \\
(\mathbf{g})\end{array}$ & $\begin{array}{c}\text { Volume } \\
(\mathbf{m L})\end{array}$ & $\begin{array}{c}\text { Time } \\
\mathbf{( h )}\end{array}$ & $\begin{array}{c}\text { Temperature } \\
\left({ }^{\circ} \mathbf{C}\right)\end{array}$ & Solvent & Result (ppm) \\
\hline 1 & Tinctures & - & - & - & $\begin{array}{c}\text { Room } \\
\text { Temperature }\end{array}$ & Ethanol/Water & Only free bases \\
\hline 2 & Maceration & 0.2 & 10 & 16 & $\begin{array}{c}\text { Room } \\
\text { Temperature }\end{array}$ & Methanol & Reference Point \\
\hline 3 & Infusion & 3.3 & 200 & 10 & Boiling Point. & Water & High contents \\
\hline 4 & Decoctions & 3.3 & 200 & 10 & Boiling Point & Water & High contents \\
\hline
\end{tabular}


For the determination of PAs (see Table 4), most research groups applied GC-MS using ionization methods such as electron impact (EI) $[16,30,34]$ or chemical Ionization (CI) $[28,30]$ in negative or positive ion mode. Edgar et al. applied FAB (fast atom bombardment), a rarely used ionization technique in MS [28]. No data regarding the sensitivity were reported by them, thus no advantages of the different ionization techniques can be stated. Colegate et al. [31] and Kast et al. [32] used liquid chromatography with mass spectrometric determination of PAs. Kast achieved an LoQ of $1.0 \times 10^{-3}-3.0 \times 10^{-3} \mathrm{ppm}$ by using a triple quadrupole and improved sensitivity (LoD: $1.0 \times 10^{-3}$ ppm; LoQ: $3.0 \times 10^{-3} \mathrm{ppm}$ ) applying a high-resolution q-ToF [32]. Both groups achieved this high sensitivity due to the usage of selective detection methods, which should be considered state-of-the-art for the determination of PAs. Other research groups address analytics in a simpler way by using TLC for purification $[27,29,33,34]$ or analysis [30] together with chloro-anillin or Mattocks reagent for visualization.

\subsection{Heliotropium}

Heliotropium belongs to the subgenus Heliotropiiodeae within the borage family. In traditional medicine, Heliotrpium indicum is used to treat abdominal pain, amenorrhea, dysmenorrhea, skin rashes, wounds, etc. [194-196]. Furthermore anti-cancer [194-196], anti-inflammatory [195,196], hypotensive [197], and anthelmenic [198] effects have been reported. Only a few extraction approaches (see Table 3) for PAs inherent in Helitropium species (see Table 2) were conducted. Methanol or either ethanol are used mostly for percolation [39-42,47,48,136] or maceration [35-38,43,45,46,132-135]. These et al. achieved, again, good results by the usage of a mixture of methanol and formic acid for maceration [125]. This procedure might be surpassed by that of Birecka et al. refluxing the samples [135,137], because, as seen before, increased temperatures have a positive effect on the yield of extracted PAs.

Most research groups were mainly interested in elucidating PA structures by applying ${ }^{1} \mathrm{H}-\mathrm{NMR}$, ${ }^{13}$ C-NMR and MS [33,35-44,46-49,132-134,136]. If quantified (see Table 4), the focus was set on determination of PA levels in young and matured leaves [135] or in elucidating different seasonal or environmental patterns [45]. Mostly GC-MS was used [45,135,137,160]. By dividing the extracts into two fractions followed by $\mathrm{Zn} / \mathrm{HCl}$ reduction of one of them, Tosun et al. quantified the PA content and the ratio of free bases to N-oxides in seeds of Helitropium [160]. Birecka et al. used four different methods for PA analysis. Identification was done by TLC, using Dragendorffs or Ehrlichs reagent. Quantification of several PAs was done by GC-MS, and the sum was determined using a photometric detection at $565 \mathrm{~nm}$ and a titration with toluene sulfonic acid [137]. These et al. applied their LC-MS/MS screening method on Heliotropium species [125]. However, in none of these articles are LoDs or LoQs stated. Nonetheless, it may be safely assumed that the LC-MS/MS method revealed the best selectivity with sensitivities in the low ppb region, as stated before.

\subsection{Lithospermum}

The genus Lithospermum includes 59 species. Lithospermum erythrorhizon, as an example, is used in Traditional Chinese Medicine (TCM) to treat wounds, burns, and dermatitis. Nowadays, it is used as adjuvant for treatment of cancer [199,200]. Additionally, anti-inflammatory [199,201], antifungal [201], and antiviral [202] effects have been reported. Different PAs are reported to be inherent in the genus Lithospermum (see Table 2). Plant material was extracted using Soxhlet extraction with methanol over seven days [50,51,53], refluxed under acidic conditions [131]. Further a fourfold sonication-supported maceration at $40{ }^{\circ} \mathrm{C}$ was performed by Pietrosiuk et al. [52]. Based on the insights gained from previous extraction experiments losses in the PA content due to long-term extractions at increased temperature cannot be excluded. However, the two other procedures seem to result in optimal PA yields.

Regarding analytics, the focus in the literature appears to be on isolation and structure elucidation $[50,51,53]$ rather than selective and sensitive PA determination (see Table 4). TLC was mostly used for purification, e.g., prior to GC-MS analysis [50,51]. For example, Pietrousk et al. determined shikonin derivatives inherent in hairy roots. They separated them by TLC followed by visualization with 
Ehrlichs reagent and GC-MS analysis [52]. Mroczek et al. repeatedly tested his HPLC-DAD-thermobeam MS method [131]. However, no quantification results are reported.

\subsection{Petasites}

About 15 species are known to belong to the genus Petasites and are distributed in the northern regions in the world. Several of them are used as herbal supplement due to their antispasmodic and anti-inflammatory effects and are included in herbal medicinal products as agent for treatment of spasms of urogenital tract, gastrointestinal colic and dysmenorrhea [203]. It is currently investigated in clinical trials for its effectiveness in migraine prophylaxis [204]. For Petasites, different inherent PAs have been reported (see Table 2). They were extracted using maceration [55,57-59], refluxing [54] or Soxhlet [55] (see Table 3). Schenk et al. analyzed a $\mathrm{CO}_{2}$-Extract [138] and Knez et al. developed a procedure with propane (HPPE, high pressure propane extraction) [139] for large scale extraction of PAs. Niwa et al. showed some evaluation of the PA extraction efficiency (see Table 6) [55]. They extracted P. japonicus samples on the one hand with boiling water and on the other hand with ethanol by Soxhlet for $24 \mathrm{~h}$. They stated that only half of the PAs (54\%) could be extracted with hot boiled water compared to the ethanolic extraction procedure. However, due to the different solvents, time, and procedures applied, it is difficult to compare the results. It can be suggested that an increased PA content is achieved if ethanol is used at increased temperatures for elongated extraction times.

Table 6. Overview of PA content extracted with two different extraction procedures from Petasites. The results correspond to the sum of petasitenine, neopetasitenine, senkirkine, and otosenine [55].

\begin{tabular}{cccccccc}
\hline Technique & $\begin{array}{c}\text { Sample } \\
(\mathbf{g})\end{array}$ & $\begin{array}{c}\text { Volume } \\
(\mathbf{m L})\end{array}$ & $\begin{array}{c}\text { Time } \\
\mathbf{( h )}\end{array}$ & $\begin{array}{c}\text { Temperature } \\
\left({ }^{\circ} \mathbf{C}\right)\end{array}$ & Solvent & $\begin{array}{c}\text { Result } \\
(\text { ratio) }\end{array}$ \\
\hline 1 & Soxhlet & 10 & - & 24 & Bp. & Ethanol & 1.0 \\
\hline 2 & Boiling & 10 & 300 & 1 & Bp. & Water & 0.5 \\
\hline
\end{tabular}

Considering analytics of Petasites (see Table 4), Wildi et al. developed a TLC method with UV detection accomplishing a LoD of 1 ppm, which can compete with HPLC- and GC-based techniques [57]. PAs in the genus Petasites were analyzed in most cases by liquid chromatography. Schenk et al. used a coupling of UHPLC with ToF-MS [138] and achieved a quantification limit of 0.002 ppm (LoD not given) for Petasites. That sensitivity limit was not reached by combination of ToF-MS with conventional HPLC separation (LoD: 0.01 ppm; LoQ: 0.5 ppm) [56,205]. One explanation for the higher sensitivity is that peaks achieved by UHPLC are narrower and therefore higher due to smaller particles and higher pressure used. Satisfying results covering a LoQ from 0.35 to $25.0 \mathrm{ppm}$ were also achieved by using UV detection. Because of missing chromophores, Niwa et al. determined PAs with a RI (refractive index) detector [55]. The smallest calibration point was set at $10.0 \mathrm{ppm}$, leaving thus the question regarding the LoQ unanswered. Selective and sensitive quantification of PAs without prior chromatographic separation was achieved by using an enzyme linked immunosorbent assay (ELISA) specific for retrorsine [57-59]. Interesting results were achieved by Langer et al. developing antibodies against retrorsine for the determination of senecionine; selectivity was shown and a LoD of $0.1 \mathrm{ppm}$ in plant material was reached [58]. A disadvantage is that only one PA is determined.

\subsection{Senecio}

More than 1000 subspecies of the genus Senecio are distributed worldwide. Therefore, several of them were investigated for their medicinal effects. For example, Senecio scandens Buch.-Ham. ExD. Don is exported as OTC in traditional Chinese medicine for treating bacterial diarrhea, enteritis, conjunctivitis, and respiratory tract infections [206] or in Africa against malaria [207] or hypertension [208]. Other species were tested for their relaxant effects [209] as well as anti-inflammatory [155,206,209], antimicrobial [155,206], antileptospirosis [206], hepaprotective [206], 
anti-infusorial [206], antioxidant [206,210-214], antiviral [206,215,216], antitumoral [155,206,217], analgesic [206], anti-tuberculosis [218], anti-spastic [155], and antibacterial [103] characteristics. In several Senecio species, 39 different PAs have been identified (see Table 2).

Maceration under acidic conditions was mostly applied, e.g., $0.05 \mathrm{M} \mathrm{HCl}[65,104,140], 0.1$ $\mathrm{M} \mathrm{HCl}$ [92], $1 \mathrm{M} \mathrm{HCl}$ [68], $0.05 \mathrm{M} \mathrm{H}_{2} \mathrm{SO}_{4}$ [72], $0.1 \mathrm{M} \mathrm{H}_{2} \mathrm{SO}_{4}$ [63,95], or $0.4 \mathrm{M}$ formic acid [66], as well as methanol $[64,75,85,97,106,142,143,219,220]$, ethanol $[79,84,109,144,146]$, or other organic mixtures $[73,98]$. A large scale maceration apparatus, based on acidic solvents, was developed by Craig et al. [221]. Alternative techniques such as ultrasonic [65], supercritical fluid (SFE) [78], continuous [101], and cold ion extraction [81] were performed as well. Extractions at increased temperatures were mostly performed by Soxhlet $[14,74,76,77,82,83,91,96,99,103,108,145,147-151,165]$ or refluxing $[25,88,105]$ with the extraction of Senecio studied by a few research groups in more detail.

Hartmann et al. compared the spontaneous reduction of $\mathrm{N}$-oxides if Soxhlet extraction or maceration was applied. They showed that up to $50 \%$ of the N-oxides were reduced during prolonged Soxhlet extraction [72] due to thermal degradation (see Table 7).

Table 7. Overview on the extraction experiments for Senecio by Hartmann et al. Results correspond to the content of free PA bases determined by GC-MS, and N-oxides by HPLC-UV [72]. Missing information is characterized by "-".

\begin{tabular}{cccccccc}
\hline & Technique & $\begin{array}{c}\text { Sample } \\
(\mathbf{g})\end{array}$ & $\begin{array}{c}\text { Volume } \\
\mathbf{( m L )}\end{array}$ & $\begin{array}{c}\text { Time } \\
\mathbf{( h )}\end{array}$ & $\begin{array}{c}\text { Temperature } \\
\left({ }^{\circ} \mathbf{C}\right)\end{array}$ & Solvent & Result (\%) \\
\hline 1 & Maceration & $6-10$ & 20 & 0.5 & $\begin{array}{c}\text { Room } \\
\text { Temperature }\end{array}$ & $\begin{array}{c}\text { Sulfuric Acid } \\
0.1 \mathrm{~N}\end{array}$ & $5^{*}$ \\
\hline 2 & Soxhlet & - & - & 48 & Boiling Point & Methanol & $44^{*}$ \\
\hline \multicolumn{7}{c}{$*$ percentage of free bases with reference to the overall PA content. }
\end{tabular}

Bicchi et al. varied pressure and temperature of SFE, and compared the results with Soxhlet extraction (see Table 8) [78]. It can be concluded that both temperature (Experiment 2 vs. 4) and pressure (Experiment 3 vs. 4) have a significant influence on the extraction yield. However, this study does not specify as to which parameter is more important. This may therefore constitute additive effects, as despite the higher temperature applied during Soxhlet extraction SFE revealed higher contents. This underlines the importance of increased pressures for an exhaustive extraction. The evaluation of the ideal Soxhlet conditions was done by varying the sample amount of $S$. inaequidens between 1 and $25 \mathrm{~g}$ and the extraction time between 0.5 and $8 \mathrm{~h}$. As a result, they limited the extraction time to $4 \mathrm{~h} \mathrm{[76],} \mathrm{which} \mathrm{may} \mathrm{be} \mathrm{a} \mathrm{further} \mathrm{evidence} \mathrm{for} \mathrm{thermal} \mathrm{degradation.}$

Table 8. Overview of the extraction experiments by Bicchi et al. To optimize the SFE extraction method for Senecio. The results correspond to the sum of senecionine and seneciphylline [78]. Missing information is characterized by "-".

\begin{tabular}{cccccccc}
\hline & Technique & $\begin{array}{c}\text { Sample } \\
(\mathbf{g})\end{array}$ & $\begin{array}{c}\text { Volume } \\
(\mathbf{m L})\end{array}$ & $\begin{array}{c}\text { Time } \\
\mathbf{( h )}\end{array}$ & $\begin{array}{c}\text { Temperature } \\
\left({ }^{\circ} \mathbf{C}\right)\end{array}$ & $\begin{array}{c}\text { Solvent/ } \\
\text { Pressure }\end{array}$ & $\begin{array}{c}\text { Result } \\
(\mathbf{p p m})\end{array}$ \\
\hline 1 & Soxhlet & 10 & - & 4 & Boiling Point & $\begin{array}{c}\text { Methanol } \\
\text { ambient }\end{array}$ & $0.74 * / 2.39 * *$ \\
\hline 2 & SFE & 0.5 & 80 & 4 & 50 & $\begin{array}{c}\text { Methanol/ } \\
\text { CO } 215 \mathrm{MPa}\end{array}$ & $0.68 * / 2.92 * *$ \\
\hline 3 & SFE & 0.5 & 80 & 4 & 55 & $\begin{array}{c}\text { Methanol/ } \\
\text { CO }{ }_{2} 10 \mathrm{MPa}\end{array}$ & $0.65 * / 2.74 * *$ \\
\hline 4 & SFE & 0.5 & 80 & 4 & 55 & $\begin{array}{c}\text { Methanol/ } \\
\mathrm{CO}_{2} 15 \mathrm{MPa}\end{array}$ & $0.84 * / 3.24 * *$ \\
\hline 5 & SFE & 0.5 & 80 & 4 & 60 & $\begin{array}{c}\text { Methanol/ } \\
\mathrm{CO}_{2} 15 \mathrm{MPa}\end{array}$ & $0.81 * / 3.16^{* *}$ \\
\hline
\end{tabular}

* Senecio inaequidens L.; ${ }^{* *}$ Senecio cordatus L. 
Kopp et al. [122] investigated the influence of solvent (acidic or basic), concentration (1\% or $5 \%$ ), temperature $\left(25-125^{\circ} \mathrm{C}\right)$, and pressure (see Table 9) using PLE. The results were compared with a BfR-based maceration method [222]. It was shown that solvent is one of the most important parameters. Temperature dependent differences of up to $600 \mathrm{ppm}$ in final PA content were shown. No effect of temperature was observed between 50 and $75{ }^{\circ} \mathrm{C}$, but, if increased above $100{ }^{\circ} \mathrm{C}$, dependent on solvent, a loss of PAs could be detected. This loss can be correlated with PA degradation caused by reactive side chains. Comparing these PA contents with the maceration-based method revealed higher PA yields of up to $380 \mathrm{ppm}$ at moderately increased temperature and increased pressure. The direct influence of pressure could not be clarified during this study.

Table 9. Overview on the extraction experiments by Kopp et al. using PLE to investigate the influence of different solvents at different temperatures on the extraction yield of PAs for the example of Senecio with reference to the BfR-based extraction method. The results correspond to the sum of erucifoline, senecionionine, senecivernine, seneciphylline, retrorsine, and their N-oxides [122].

\begin{tabular}{cccccccc}
\hline & Technique & $\begin{array}{c}\text { Sample } \\
(\mathbf{g})\end{array}$ & $\begin{array}{c}\text { Volume } \\
(\mathbf{m L})\end{array}$ & $\begin{array}{c}\text { Time } \\
(\mathbf{m i n})\end{array}$ & $\begin{array}{c}\text { Temperature } \\
\left({ }^{\circ} \mathbf{C}\right)\end{array}$ & Solvent & $\begin{array}{c}\text { Result } \\
(\mathbf{p p m})\end{array}$ \\
\hline 1 & PLE & 1 & 30 & 30 & $50 / 75 / 100 / 125$ & Phosphoric acid 1\% & $360.6 / 314.5 / 331.4 / 191.2$ \\
\hline 2 & PLE & 1 & 30 & 30 & $50 / 75 / 100 / 125$ & Phosphoric acid $5 \%$ & $409.7 / 393.6 / 396.7 / 197.6$ \\
\hline 3 & PLE & 1 & 30 & 30 & $50 / 75 / 100 / 125$ & Ammonia $1 \%$ & $177.9 / 185.2 / 218.4 / 106.6$ \\
\hline 4 & PLE & 1 & 30 & 30 & $50 / 75 / 100 / 125$ & Ammonia 5\% & $168.9 / 291.6 / 212.8 / 146.3$ \\
\hline 5 & PLE & 1 & 30 & 30 & $50 / 75 / 100 / 125$ & Sulfuric acid $1 \%$ & $168.4 / 251.1 / 119.5 / 146.5$ \\
\hline 6 & PLE & 1 & 30 & 30 & $50 / 75 / 100 / 125$ & Sulfuric acid 5\% & $250.7 / 253.8 / 85.1 / 153.8$ \\
\hline 7 & PLE & 1 & 30 & 30 & $50 / 75 / 100 / 125$ & Acetic acid $1 \%$ & $787.5 / 863.0 / 558.2 / 234.6$ \\
\hline 8 & PLE & 1 & 30 & 30 & $50 / 75 / 100 / 125$ & Acetic acid 5\% & $831.1 / 838.0 / 603.0 / 195.9$ \\
\hline 9 & PLE & 1 & 30 & 30 & $50 / 75 / 100 / 125$ & Formic acid 1\% & $798.9 / 776.9 / 574.9 / 255.5$ \\
\hline 10 & PLE & 1 & 30 & 30 & $50 / 75 / 100 / 125$ & Formic acid 5\% & $880.2 / 774.4 / 729.2 / 208.9$ \\
\hline 11 & BfR based & 2 & 40 & 30 & \multirow{2}{*}{ RT } & Formic Acid/ & \\
\hline
\end{tabular}

Zhang et al. compared refluxing (methanol), soaking or sonication assisted extraction of samples in aqueous $\mathrm{HCl}$ [104]. They decided to use sonication experiments for optimizing adonifoline content, because of the easy, fast, and rugged handling without thermal degradation. A L9 (34) orthogonal study design (also referred to as the Taguchi design) (see Table 10) was used.

Varied parameters were solvent volume, concentration, and extraction time. Zhang et al. concluded that, in the case of adonifoline, the most important factor appears to be time followed by concentration and volume. Hence, the best results were achieved if low concentrations of hydrochloric acid were applied for a long time, i.e., $40 \mathrm{~min}$.

To summarize the results for the extraction of plants of the genus Senecio, it may concluded that best yields can be achieved by applying acidic solvents at increased temperatures for short time periods preferably at high pressures. 
Table 10. Overview on experiments by Zhang et al. To optimize the extraction of adenofiline by sonication. The results represent the content of adenofiline determined by HPLC-MS/MS [104].

\begin{tabular}{cccccccc}
\hline Technique & $\begin{array}{c}\text { Sample } \\
\mathbf{( g )}\end{array}$ & $\begin{array}{c}\text { Volume } \\
(\mathbf{m L})\end{array}$ & $\begin{array}{c}\text { Time } \\
\mathbf{( m i n )}\end{array}$ & $\begin{array}{c}\text { Temperature } \\
\left.\mathbf{(}{ }^{\circ} \mathbf{C}\right)\end{array}$ & Solvent & $\begin{array}{c}\text { Result } \\
(\mathbf{p p m})\end{array}$ \\
\hline 1 & Sonication & 0.3 & 10 & 10 & $\begin{array}{c}\text { Room } \\
\text { Temperature }\end{array}$ & $\begin{array}{c}\text { Methanol/HCl } \\
0.2 \%\end{array}$ & 85.2 \\
\hline 2 & Sonication & 0.3 & 10 & 20 & $\begin{array}{c}\text { Room } \\
\text { Temperature }\end{array}$ & $\begin{array}{c}\text { Methanol/HCl } \\
1.0 \%\end{array}$ & 75.9 \\
\hline 3 & Sonication & 0.3 & 10 & 40 & $\begin{array}{c}\text { Room } \\
\text { Temperature }\end{array}$ & $\begin{array}{c}\text { Methanol/HCl } \\
5.0 \%\end{array}$ & 85.5 \\
\hline 5 & Sonication & 0.3 & 25 & 20 & $\begin{array}{c}\text { Room } \\
\text { Temperature }\end{array}$ & $\begin{array}{c}\text { Methanol/HCl } \\
0.2 \%\end{array}$ & 86.6 \\
\hline 6 & Sonication & 0.3 & 25 & 40 & $\begin{array}{c}\text { Room } \\
\text { Temperature }\end{array}$ & $\begin{array}{c}\text { Methanol/HCl } \\
1.0 \%\end{array}$ & 86.1 \\
\hline 7 & Sonication & 0.3 & 25 & 10 & $\begin{array}{c}\text { Room } \\
\text { Temperature }\end{array}$ & $\begin{array}{c}\text { Methanol/HCl } \\
5.0 \%\end{array}$ & 74.5 \\
\hline 8 & Sonication & 0.3 & 40 & 40 & $\begin{array}{c}\text { Room } \\
\text { Temperature }\end{array}$ & $\begin{array}{c}\text { Methanol/HCl } \\
0.2 \%\end{array}$ & 86.8 \\
\hline
\end{tabular}

Analyzing PAs in the genus Senecio (see Table 4), the whole bandwidth of chromatographic techniques were used. Unfortunately, the achievable sensitivity is rarely reported. For example, GC coupled with FID $[68,72,77,78,82,84,87,95]$, NPD [68,72,87], or MS [62,63,67,68,73-77,83,84,87,92,94,99,103] were used but no LoDs or LoQs are stated. The same holds true for HPLC-based analyses. Only a few research groups published their achieved sensitivities after optimization. Zhang et al. reported via MS/MS detection based methods a LoD of $0.5 \times 10^{-3} \mathrm{ppm}$ [104]. A comparable result was achieved for adinofoline in UV, after previous derivatization with chloro-aniline [140]. Schaneberg et al. reported only medium sensitivity when ELSD was coupled to HPLC [64]. The best $\operatorname{LoD}\left(0.3-1.1 \times 10^{-6} \mathrm{ppm}\right)$ was achieved by Zhou et al. with UHPLC combining high resolution with short analysis times and reduced solvent consumption [65]. Determination without previous separation was mainly done by quantitative NMR (q-NMR) and enzyme linked immunosorbent assay (ELISA). Pieters et al. compared q-NMR $\left({ }^{1} \mathrm{H}\right.$ and $\left.{ }^{13} \mathrm{C}\right)$ with GC and concluded that there is a lack of selectivity due to the complex spectrum with much overlapping signals using ${ }^{1} \mathrm{H}-\mathrm{NMR}$. In contrast, ${ }^{13} \mathrm{C}-\mathrm{NMR}$ might be more suitable, but it cannot compete with the sensitivity achieved by GC-MS [80]. Langer et al. developed specific antibodies against retrorsine and immobilized them for the determination of senecionine, the main alkaloid of genus Senecio. Despite an LoD of $0.023 \times 10^{-3} \mathrm{ppm}$ and the resolved cross-reactivities against monocrotaline, senecyphilline, retrorsine- $\mathrm{N}$-oxide, and senkirkine, its usage is limited to a single PA [58].

\subsection{Symphytum}

Comfrey is used as a medicinal plant based on its anti-inflammatory and analgesic effects. Multiple trials have demonstrated the efficacy of comfrey preparations for treatment of pain, inflammation, and swelling of muscles in degenerative arthritis, sprains, acute myalgia in the back, contusions, and strains after sport injuries [223]. Several PAs were identified in roots or leaves of Symphytum (see Table 2). The dried, freeze-dried [153], or nitrogen-ground [224] plant parts were extracted by various extraction procedures and solvents (see Table 3 ). In most cases, maceration with or without sonication was utilized for PA extraction [64,93,116,152-155]. Other procedures such as refluxing [54,116,152], percolating [152], 
HPWE [116] or PLE [122] were used too. Only limited studies were devoted to investigate the effect of different extraction conditions on the yield of PAs from Symphytum. The most detailed study was presented by Mroczek et al. investigating the effect of solvents (organic, aqueous, acidified, alkalified, or mixtures), temperature, time, or technique (maceration, percolation, sonication, or refluxing) [152] (see Table 11).

Table 11. Overview on the extraction experiments by Mroczek et al. To investigate the influence of extraction techniques using different solvents for different times at different temperatures on the extraction yield of PAs for the example of Symphytum. The results correspond to the sum of PAs quantified by UV-Vis [152] (1st, first extraction; 2nd, second extraction).

\begin{tabular}{|c|c|c|c|c|c|c|c|}
\hline & Technique & $\begin{array}{l}\text { Sample } \\
\text { (g) }\end{array}$ & $\begin{array}{l}\text { Volume } \\
(\mathrm{mL})\end{array}$ & $\begin{array}{l}\text { Time } \\
\text { (h) }\end{array}$ & $\begin{array}{c}\text { Temperature } \\
\left({ }^{\circ} \mathrm{C}\right)\end{array}$ & Solvent & $\begin{array}{c}\text { Result } \\
\text { (ppm) }\end{array}$ \\
\hline 1 & Maceration & 1 & 100 & 6 & $\begin{array}{c}\text { Room } \\
\text { temperature }\end{array}$ & Methanol & 802 \\
\hline 2 & Maceration & 1 & 100 & 12 & $\begin{array}{c}\text { Room } \\
\text { temperature }\end{array}$ & Methanol & 695 \\
\hline 3 & Maceration & 1 & 100 & 18 & $\begin{array}{c}\text { Room } \\
\text { temperature }\end{array}$ & Methanol & 854 \\
\hline 4 & Maceration & 1 & 100 & 12 & $50-60$ & Methanol & 1081 \\
\hline 5 & Reflux & 1 & 100 & 2 (1st) & Boiling Point & Methanol & 1251 \\
\hline 6 & Reflux & 1 & 100 & 2 (2nd) & Boiling Point & Methanol & 155 \\
\hline 7 & Percolation & 5 & 500 & 2 & $\begin{array}{c}\text { Room } \\
\text { temperature }\end{array}$ & Methanol & 1051 \\
\hline 8 & Percolation & 2 & 200 & 2 & $\begin{array}{c}\text { Room } \\
\text { temperature }\end{array}$ & Methanol & 640 \\
\hline 9 & Maceration & 1 & 100 & 10 & $\begin{array}{c}\text { Room } \\
\text { temperature }\end{array}$ & $\begin{array}{c}1 \% \text { methanolic } \\
\text { solution of } \\
\text { tartaric acid }\end{array}$ & 1024 \\
\hline 10 & Reflux & 1 & 100 & 1 & Boiling Point & $\begin{array}{c}1 \% \text { methanolic } \\
\text { solution of } \\
\text { tartaric acid }\end{array}$ & 1092 \\
\hline 11 & Reflux & 1 & 100 & 2 & Boiling Point & $\begin{array}{c}1 \% \text { methanolic } \\
\text { solution of } \\
\text { tartaric acid }\end{array}$ & 1301 \\
\hline 12 & Reflux & 1 & 100 & 4 & Boiling Point & $\begin{array}{c}1 \% \text { methanolic } \\
\text { solution of } \\
\text { tartaric acid }\end{array}$ & 1155 \\
\hline 13 & Sonication & 1 & 100 & 0.5 & $\begin{array}{l}\text { Room } \\
\text { temperature }\end{array}$ & $\begin{array}{c}1 \% \text { methanolic } \\
\text { solution of } \\
\text { tartaric acid }\end{array}$ & 436 \\
\hline 14 & Maceration & 1 & 100 & 18 & $\begin{array}{c}\text { Room } \\
\text { temperature }\end{array}$ & Ethanol 95\% & 363 \\
\hline 15 & Reflux & 1 & 100 & 4 & Boiling Point & Ethanol 95\% & 1258 \\
\hline 16 & Maceration & 1 & 100 & 6 & $\begin{array}{c}\text { Room } \\
\text { temperature }\end{array}$ & $2.5 \% \mathrm{HCl}$ & 498 \\
\hline 17 & Reflux & 1 & 100 & 0.5 & Boiling Point & $2.5 \% \mathrm{HCl}$ & 304 \\
\hline 18 & Reflux & 1 & 100 & 2 & Boiling Point & $2.5 \% \mathrm{HCl}$ & 214 \\
\hline 19 & Maceration & 1 & 100 & 1 & $\begin{array}{c}\text { Room } \\
\text { temperature }\end{array}$ & $\begin{array}{c}\text { Chlorofom/ } \\
\text { MeOH/Ammonia }\end{array}$ & 229 \\
\hline 20 & Sonication & 1 & 100 & 0.5 & $\begin{array}{c}\text { Room } \\
\text { temperature }\end{array}$ & 5\% Acetic Acid & 650 \\
\hline 21 & Reflux & 1 & 100 & 2 & Boiling Point & $\begin{array}{l}1 \% \text { methanolic } \\
\text { solution of } \\
\text { ascorbic acid }\end{array}$ & 163 \\
\hline
\end{tabular}


The significant influence of the solvent could be shown by comparing the results of a $1 \%$ methanolic solution of tartaric acid (highest yields) with methanol (second highest yield), 2.5\% aqueous hydrochloric acid (third highest yield), followed by ethanol 95\% and an alkalified mixture of methanol and chloroform. However, it was also shown that this effect can be eliminated at elevated temperatures. However, increased temperatures and selecting the least efficient solvent may result in strongly decreased PA amounts. For example, high temperatures in combination with hydrochloric or ascorbic acid resulted in decreased amounts. Considering time, extended extraction periods at room temperature result in higher yields, yet in losses at higher temperatures (4-h reflux Experiment 12 compared to 2-h reflux experiment), which may come from degradation. Overall, experiments done by Mroczek et al. show that contents between 163 and 1300 ppm were reached for the same plant material dependent on the selected extraction parameters. In summary, acidic solvents and increased temperatures for short time periods appear to be the parameters of choice.

Feng Liu et al. extracted samples by sonication, refluxing and pressurized hot water extraction. Solvent (methanol, ethanol, and mixtures), time, and temperature were varied (see Table 12). The 6 ppm higher content using water/methanol for extraction reflects that solvents have an important influence. In combination with an increased temperature (i.e., refluxing), a fourfold content of lycopsamin was achieved, which reveals the additional positive effect of increased temperatures. Even PHWE lead to higher lycopsamine contents compared to those obtained with sonication [116].

Table 12. Overview on the extraction experiments by Feng Liu et al. to investigate the influence of the extraction technique, solvent, extraction time, and temperature on the extraction yield of PAs in Symphytum. Results correspond to lycopsamine determined by HPLC- ESI-MS [116].

\begin{tabular}{|c|c|c|c|c|c|c|c|}
\hline & Technique & $\begin{array}{l}\text { Sample } \\
\text { (g) }\end{array}$ & $\begin{array}{l}\text { Volume } \\
\text { (mL) }\end{array}$ & $\begin{array}{l}\text { Time } \\
(\min )\end{array}$ & $\begin{array}{c}\text { Temperature } \\
\left({ }^{\circ} \mathrm{C}\right)\end{array}$ & Solvent & $\begin{array}{l}\text { Result } \\
(\mathrm{ppm})\end{array}$ \\
\hline 1 & Sonication & 1 & 50 & 10 & $\begin{array}{c}\text { Room } \\
\text { Temperature }\end{array}$ & $\begin{array}{c}\text { Methanol/Water } \\
(50 / 50)\end{array}$ & approx. 7.5 \\
\hline 2 & Sonication & 1 & 50 & 10 & $\begin{array}{c}\text { Room } \\
\text { Temperature }\end{array}$ & $\begin{array}{l}\text { Methanol/Water } \\
\text { (50/50), pH: } 2.5\end{array}$ & approx. 7.5 \\
\hline 3 & Sonication & 1 & 50 & 10 & $\begin{array}{c}\text { Room } \\
\text { Temperature }\end{array}$ & $\begin{array}{c}\text { Methanol/ } \\
\text { Chloroform (15/85) }\end{array}$ & approx. 1.5 \\
\hline 4 & Sonication & 1 & 50 & 10 & $\begin{array}{c}\text { Room } \\
\text { Temperature }\end{array}$ & Methanol & approx. 3.0 \\
\hline 5 & Sonication & 1 & 50 & 10 & $\begin{array}{c}\text { Room } \\
\text { Temperature }\end{array}$ & Ethanol 95\% & approx. 1.0 \\
\hline 6 & Reflux & 1 & 60 & 60 & 65 & $\begin{array}{l}\text { Methanol/Water } \\
(50 / 50)\end{array}$ & approx. 30 \\
\hline 7 & PHWE & 1 & 60 & 40 & 60 & $\begin{array}{c}\text { Methanol/Water } \\
(50 / 50)\end{array}$ & approx. 12.5 \\
\hline 8 & PHWE & 1 & 60 & 40 & 80 & $\begin{array}{c}\text { Methanol/Water } \\
(50 / 50)\end{array}$ & approx. 10.0 \\
\hline
\end{tabular}

Kopp et al. studied the extraction with PLE [122] and compared the results with the BfR-based extraction method [222]. Solvent, concentration, and temperature were varied systematically, while pressure was held constant during PLE experiments (see Table 13). 
Table 13. Overview on the extraction experiments carried out to investigate the influence of different solvents, at different temperatures on the extraction yield of PAs of Symphytum with PLE and the BfR-based extraction method. The result corresponds to the sum of lycopsamine and intermedine quantified by LC/MS/MS [122].

\begin{tabular}{cccccccc}
\hline & Technique & $\begin{array}{c}\text { Sample } \\
(\mathbf{g})\end{array}$ & $\begin{array}{c}\text { Volume } \\
(\mathbf{m L})\end{array}$ & $\begin{array}{c}\text { Time } \\
(\mathbf{m i n})\end{array}$ & $\begin{array}{c}\text { Temperature } \\
\left({ }^{\circ} \mathbf{C}\right)\end{array}$ & Solvent & Result (ppm) \\
\hline 1 & PLE & 1 & 30 & 30 & $50 / 75 / 100 / 125$ & Phosphoric acid $1 \%$ & $389.1 / 485.5 / 312.3 / 615.8$ \\
\hline 2 & PLE & 1 & 30 & 30 & $50 / 75 / 100 / 125$ & Phosphoric acid $5 \%$ & $564.4 / 619.5 / 677.3 / 586.8$ \\
\hline 3 & PLE & 1 & 30 & 30 & $50 / 75 / 100 / 125$ & Formic acid $1 \%$ & $321.3 / 318.4 / 422.6 / 462.6$ \\
\hline 4 & PLE & 1 & 30 & 30 & $50 / 75 / 100 / 125$ & Formic acid 5\% & $474.1 / 386.1 / 510.6 / 472.9$ \\
\hline 5 & PLE & 1 & 30 & 30 & $50 / 75 / 100 / 125$ & Sulfuric acid 1\% & $481.7 / 444.2 / 455.2 / 486.1$ \\
\hline 6 & PLE & 1 & 30 & 30 & $50 / 75 / 100 / 125$ & Sulfuric acid 5\% & $726.6 / 716.4 / 711.0 / 502.4$ \\
\hline 7 & BfR based & 2 & 40 & 30 & RT & $\begin{array}{c}\text { Formic } \\
\text { Acid/Methanol/Water }\end{array}$ & 251.7 \\
\hline
\end{tabular}

Due to the inherent mucilage, comfrey was a challenging matrix resulting in cell clogging during extraction. Therefore, ammonia and acetic acid were not considered. Best yields were shown for PLE extraction on increased temperatures with strong acids at high concentration levels (e.g., sulfuric acid). The evaluations showed that solvent was the most important factor, but selecting a less ideal solvent composition may be compensated by increasing the extraction temperature, as shown by Mroczek et al. [152]. Comparison with the maceration method reveal the positive influence of temperature and pressure, because a threefold higher content of PAs was found in PLE extracts.

On the analysis, Roeder et al. [169] and Mroczek et al. [152] used a photometric quantification method for determining the sum of PAs. A LoD of 1 ppm was reported by Roeder for this method. In the case of comfrey, which has high contents of PAs, this may be acceptable. If smaller concentrations are apparent, matrix effects due to accompanying substances have to be considered. Most research groups used methods such as HPLC and GC for quantification, and TLC and CCC (counter current chromatography) for preparative purification [113]. Janes et al. used TLC for analytical purposes and developed a screening method with densiometric detection (LoD: 22 ppm) [168]. Schaneberg et al. improved selectivity using LC-ELSD (Evaporating Light Scattering Detection), but only reached a LoD of 40 ppm [64]. Better results were achieved by Mroczek et al. [54], who developed a sensitive HPLC- DAD method with a LoD of $0.06 \mathrm{ppm}$. Determinations of PAs by GC, to enhance sensitivity, were made mainly by MS [114,153] and FID [93,114] as detection method. No LoDs have been reported for these methods in the literature. Similar sensitivity to MS/MS was achieved by Oberlies et al. using GC coupled with a nitrogen selective detector (NPD) [154]. Other methods have an LoD of approximately $1 \times 10^{-3} \mathrm{ppm}$. The sensitivity can be improved by using an orbitrap that enables $\mathrm{MS}^{\mathrm{n}}$, but no LoD was stated by Liu et al. [116].

\subsection{Tussilago}

Herbal preparations of Tussilago were used in traditional medicine for treating cough, phlegm, bronchitic, and asthmatic conditions [225]. Today, different articles exist that prove the antimicrobial [226,227], antitubercular [228], antioxidant [229,230], neuroprotective [229], antitussive [225], expectorant [225], and anti-inflammatory [225] effects. Senkirkin is the most commonly reported PA detected in Tussilago (see Table 2). The different techniques and solvents used for extraction are listed in Table 3. Maceration of the dried plant $[118,119,121,156]$ was found to be the preferred procedure. Only a few research groups investigated the extraction behavior of inherent PAs.

Lebada et al. studied the influence of solvent, time, temperature, plant-to-solvent ratio, and the extraction procedure applied on the extraction efficiency of senkirkine [118] (see Table 14). 
Table 14. Overview on experiments by Lebada et al. To investigate extraction parameter on the yield of Senkirkine from Tussilago quantified by CE-UV [118].

\begin{tabular}{|c|c|c|c|c|c|c|c|}
\hline & Technique & $\begin{array}{l}\text { Sample } \\
\text { (g) }\end{array}$ & $\begin{array}{c}\text { Volume } \\
\text { (mL) }\end{array}$ & $\begin{array}{l}\text { Time } \\
(\mathrm{min})\end{array}$ & $\begin{array}{c}\text { Temperature } \\
\left({ }^{\circ} \mathrm{C}\right)\end{array}$ & Solvent & $\begin{array}{l}\text { Result } \\
(\mathrm{ppm})\end{array}$ \\
\hline 1 & Flask & 15 & 1500 & 30 & $\begin{array}{c}\text { Room } \\
\text { Temperature }\end{array}$ & Water & 2.9 \\
\hline 2 & Reflux & 15 & 1500 & 15 & Boiling Point & Water & 9.3 \\
\hline 3 & Reflux & 10 & 1000 & 15 & Boiling Point & $\begin{array}{l}\text { Water acidified } \\
\text { with citric acid }\end{array}$ & 8.0 \\
\hline 4 & Reflux & 10 & 300 & 15 & Boiling Point & $\begin{array}{l}\text { Methanol/Water } \\
\text { (50/50) acidified } \\
\text { with citric acid }\end{array}$ & 8.0 \\
\hline 5 & Reflux & 10 & 600 & 15 & Boiling Point & $\begin{array}{l}\text { Methanol/Water } \\
\text { (50/50) acidified } \\
\text { with citric acid }\end{array}$ & 11.2 \\
\hline 6 & Reflux & 10 & 1000 & 15 & Boiling Point & $\begin{array}{l}\text { Methanol/Water } \\
\text { (50/50) acidified } \\
\text { with citric acid }\end{array}$ & 11.0 \\
\hline 7 & Reflux & 10 & 1000 & 120 & Boiling Point & $\begin{array}{l}\text { Methanol/Water } \\
\text { (50/50) acidified } \\
\text { with citric acid }\end{array}$ & 9.2 \\
\hline 8 & Reflux & 10 & 300 & 15 & Boiling Point & $\begin{array}{l}\text { Methanol/Water } \\
\text { (50/50) alkalized } \\
\text { with ammonia }\end{array}$ & 8.9 \\
\hline 9 & Reflux & 10 & 1000 & 15 & Boiling Point & $\begin{array}{c}\text { Methanol/Water } \\
\text { (50/50) alkalized } \\
\text { with ammonia }\end{array}$ & 8.4 \\
\hline 10 & Soxhlet & 10 & 500 & 2880 & Boiling Point & Methanol & 2.5 \\
\hline 11 & Reflux & 10 & 1000 & 15 & Boiling Point & $\begin{array}{l}\text { Methanol } \\
\text { alkalized with } \\
\text { ammonia }\end{array}$ & 5.0 \\
\hline
\end{tabular}

It was derived that a low plant-to-solvent ratio of $1 \mathrm{~g} / 60 \mathrm{~mL}$ and $1 \mathrm{~g} / 100 \mathrm{~mL}$ results in a $3 \mathrm{ppm}$ higher yields than shown for a ratio of $1 \mathrm{~g} / 30 \mathrm{~mL}$. Regarding extraction solvent, best yields were achieved by using a mixture of methanol/water (1:1) acidified with citric acid. Alkaline solvents result in a decreased senkirkine content. The influence of temperature was more drastic, as a threefold higher PA content could be obtained for samples extracted with water, when increased temperature was applied for a short time period. The opposite was shown for high temperatures over a long time period. In the case of Soxhlet extractions lasting for $48 \mathrm{~h}$, a loss of $8.7 \mathrm{ppm}$ senkirkine was noted compared to the best extraction.

Jiang et al. compared Microwave Assisted Extraction (MAE), Pressurized Hot Water Extraction (PHWE), and heating under reflux [157] to show that PHWE is suitable for extraction of PAs from Tussliago (see Table 15) After optimization, PAs extracted using MAE and PHWE were comparable to that by heating under reflux. Again, a mixture of methanol/water acidified with $\mathrm{HCl}$ was found to be the best extraction solvent. Varying the temperature in the range of $60-120^{\circ} \mathrm{C}$ did not affect the PA content significantly. It may also be concluded from this work, that using acidified solvents at increased temperatures over short time periods results in good extraction yields. 
Table 15. Overview on the extraction experiments by Jiang et al. To investigate the influence of different extraction techniques on the yield of senecionine and senkirkine extracted from Tussilago. The result correspond to the sum of senecionine and senkirkine determined by LC/MS/MS [157].

\begin{tabular}{cccccccc}
\hline Technique & $\begin{array}{c}\text { Sample } \\
(\mathbf{g})\end{array}$ & $\begin{array}{c}\text { Volume } \\
(\mathbf{m L})\end{array}$ & $\begin{array}{c}\text { Time } \\
(\mathbf{m i n})\end{array}$ & $\begin{array}{c}\text { Temperature } \\
\left({ }^{\circ} \mathbf{C}\right)\end{array}$ & Solvent & $\begin{array}{c}\text { Result } \\
(\mathbf{p p m})\end{array}$ \\
\hline 1 & MAE & 1 & 40 & 15 & $\mathrm{Bp}$. & $\begin{array}{c}\text { Water/Methanol } \\
\text { acidified with HCl }\end{array}$ & 104.4 \\
\hline 2 & Reflux & 1 & 60 & 60 & $\mathrm{Bp}$ & $1 \mathrm{~N} \mathrm{HCl}$ & 109.6 \\
\hline 3 & PHWE & 0.25 & 50 & 50 & 60 & Water & 88.2 \\
\hline 4 & Reflux & 1 & 60 & 60 & $\mathrm{Bp}$. & $1 \mathrm{~N} \mathrm{HCl}$ & 87.9 \\
\hline
\end{tabular}

Kopp et al. addressed the influence of temperature, kind of solvent (weak acid, strong acid, or base), concentration, and pressure applying pressurized liquid extraction (PLE) [122]. These results were compared with the BfR-based liquid-liquid extraction method [222]. Acidic extraction resulted in a threefold higher PA content compared to alkaline ones (see Table 16). Comparison of PLE yields with those of the BfR-based method underlines the assumption that the applied pressure increases the extraction rates significantly.

Table 16. Overview on the extraction experiments investigating the influence of different solvents, at different temperatures on the extraction yield of PAs for the example of Tussilago with reference to the BfR-based extraction method. The result corresponds to the sum of senkirkine, senecionine, and senecivernine quantified by LC/MS/MS [122].

\begin{tabular}{cccccccc}
\hline & Technique & $\begin{array}{c}\text { Sample } \\
(\mathbf{g})\end{array}$ & $\begin{array}{c}\text { Volume } \\
(\mathbf{m L})\end{array}$ & $\begin{array}{c}\text { Time } \\
(\mathbf{m i n})\end{array}$ & $\begin{array}{c}\text { Temperature } \\
\left({ }^{\circ} \mathbf{C}\right)\end{array}$ & Solvent & Result (ppm) \\
\hline 1 & PLE & 1 & 30 & 30 & $50 / 75 / 100 / 125$ & Phosphoric acid $1 \%$ & $62.3 / 63.6 / 62.0 / 62.8$ \\
\hline 2 & PLE & 1 & 30 & 30 & $50 / 75 /-0 / 125$ & Phosphoric acid $5 \%$ & $58.3 / 64.8 / 65.0 / 62.4$ \\
\hline 3 & PLE & 1 & 30 & 30 & $50 / 75 / 100 / 125$ & Ammonia $1 \%$ & $21.0 / 21.5 / 22.2 / 20.9$ \\
\hline 4 & PLE & 1 & 30 & 30 & $50 / 75 / 100 / 125$ & Ammonia $5 \%$ & $21.2 / 20.8 / 20.2 / 20.6$ \\
\hline 5 & PLE & 1 & 30 & 30 & $50 / 75 / 100 / 125$ & Sulfuric acid $1 \%$ & $60.6 / 62.0 / 65.6 / 63.4$ \\
\hline 6 & PLE & 1 & 30 & 30 & $50 / 75 / 100 / 125$ & Sulfuric acid $5 \%$ & $60.9 / 61.2 / 60.0 / 62.8$ \\
\hline 7 & PLE & 1 & 30 & 30 & $50 / 75 / 100 / 125$ & Acetic acid $1 \%$ & $59.7 / 62.4 / 62.4 / 62.8$ \\
\hline 8 & PLE & 1 & 30 & 30 & $50 / 75 / 100 / 125$ & Acetic acid 5\% & $63.7 / 60.7 / 62.6 / 63.7$ \\
\hline 9 & PLE & 1 & 30 & 30 & $50 / 75 / 100 / 125$ & Formic acid $1 \%$ & $62.8 / 62.0 / 63.3 / 64.3$ \\
\hline 10 & PLE & 1 & 30 & 30 & $50 / 75 / 100 / 125$ & Formic acid 5\% & $59.6 / 62.6 / 62.2 / 63.6$ \\
\hline 11 & BfR based & 2 & 40 & 30 & RT & Formic & \\
\hline
\end{tabular}

Summarizing the insights gained from previous results, it may be concluded that PAs are extracted best if acidic conditions at elevated temperatures and increased pressure are applied. However, sizeable extraction losses were recognized in case of long-term procedures such Soxhlet over $48 \mathrm{~h} \mathrm{[118].}$

Analytical techniques used for determining PA content in Tussilago extracts are summarized in Table 4. Culvenor et al. determined the sum of PAs of the crude extract by titration with toluene sulfonic acid [156]. Because of the lack of selectivity and sensitivity, methods with previous separation such as TLC or HPLC, based on polar, apolar, ionic, chiral, and similar interactions are used more often. Samples could be applied without cleanup or derivatization procedures and were determined by various detection methods. Mass spectrometry was preferred one because of its performance regarding sensitivity and selectivity [117,157]. Jiang et al. achieved an LoD of 0.000275 ppm for senkirkine using LC-q-ToF [157]. GC-MS was used by Nedelcheva et al. To investigate the PA distribution of the genus Tussilago native in Bulgaria [120]. 
Advantageous is the increased selectivity because of the high resolution of GC vs. liquid chromatography. Sample preparation is more time consuming because of the needed reduction step $(\mathrm{Zn} / \mathrm{HCl}$ or Serdoxit columns) for the non-volatile N-Oxides. Capillary electrophoresis (CE) provides a still better resolution power than GC. It was used by Lebada et al. To quantify the content of senkirkine and senecionine. Despite missing chromophores, with LC-Q-ToF a comparable LoD was achieved. This may be attributed to the very narrow peak shapes [118]. Cao et al. used amplified sample stacking, an online preconcentration step in combination with electrokinetic chromatography (MEKC). In this combination of chromatography and electrophoresis, PAs are separated by differential partitioning between micelles and the aqueous surrounding buffer [121].

\section{Discussion}

\subsection{Extraction Techniques}

The main aim of every extraction strategy is achieving a recovery of $100 \%$ of the analyte from the respective matrix. To assess the efficiency of various PA extraction strategies from different plant parts, the literature on thirteen relevant plant genera was reviewed regarding the selected extraction conditions. A multitude of extraction procedures and solvents were applied. Plant parts were used fresh, freeze dried, dried in oven, or frozen in liquid nitrogen. Afterwards, they were crushed, and then ground or milled to obtain a powder suitable for efficient extraction. Maceration of plant material was performed in organic, aqueous, acidic, or basic solvents, or even in mixtures thereof. Samples were extracted once or multiple times, with or without treating samples at elevated temperatures, and for time periods ranging from $30 \mathrm{~min}$ up to a few days. The same parameters (i.e., solvent, temperature, and time) were also varied for all other reported extraction procedures. Only few research reports discuss novel extraction routines such as MAE, HWPE, SFE, or PLE, whereby the pressure is an additional parameter affecting efficient extraction. As the PA content in plant matter differs with regard to subspecies, habitat of growth, soil of growth, nutrition, and/or water supply, only relative comparisons of the results obtained by different research groups are possible. Every plant collected or grown for a PA study provides an individual PA pattern and concentration level, which renders absolute comparison of the applied techniques only feasible, if the bulk of the plant material was identical. Only a few research groups have considered this aspect so far and have thus compared various parameters on a fair basis for determining optimum conditions for close to ideal PA recoveries. Suitable comparisons of the extraction procedures using essentially the same bulk material was available for four of the thirteen plant genera reviewed herein. Evaluating these studies reveals that the content of PAs varies up to $1100 \mathrm{ppm}[0.11 \%(w / w)]$ for a specific plant material, if different extraction methods, solvents, temperatures, and extraction durations were used.

In summary, it was shown that applying acidified mixtures of organic solvents at temperatures up to $100{ }^{\circ} \mathrm{C}$ for short periods of time apparently leads to optimum yields of PAs. The precise extraction conditions evidently depend on the character of the matrices and the molecular structures of the inherent pyrrolizidine alkaloids. If these aspects are considered, clustering of plant matrices is possible to extrapolate extraction conditions for a new plant material. It has to be considered that matrices with inherently robust PAs are best extracted at high temperatures with solvent mixtures containing strong acids. Comparatively simple matrices with PAs comprising sensitive functional groups are best extracted using solvent mixtures containing weak acids at slightly increased temperatures. However, for all matrices and PA properties, it was shown that short extraction times are preferred, as extractions during extended time periods resulted in significantly decreased PA recoveries.

\subsection{Analytical Techniques}

For the purpose of determining toxic substances in plants or plant extracts used for herbal preparations, appropriately sensitive and selective analytical methods are needed. Recapitulating the analytical techniques reported in literature and summarized herein, a wide range of methods 
were applied predominantly based on some form of separation technique. The determination of alkaloids as sum parameter without previous separation (i.e., photometrically, by titration, or by quantitative NMR using spin of ${ }^{1} \mathrm{H}$ or ${ }^{13} \mathrm{C}$ ) remains less pronounced and appears challenging due to potential interferences resulting from accompanying substances within these extracts. Therefore, chromatographic separations appear mandatory for ensuring sufficient selectivity and maximizing the sensitivity of the coupled detection technique. For semi-quantitative or less sensitive PA determination, thin layer chromatography was successfully applied. For visualization, Ehrlichs reagent, chloro-aniline, Mattocks procedure, or Dragendorffs reagent is used in combination with densiometric detection or detection under UV radiation. More recently, an increased usage of high- or ultra-high-performance liquid chromatography has been noticed during reviewing the pertinent literature providing higher chromatographic resolution, which was particularly successful for separating pyrrolizidine alkaloids from their N-oxides.

Due to missing chromophores, a variety of alternative detection methods including ELSD, RI, etc. were tested, yet have not achieved useful LoDs and LoQs. Hence, predominantly mass spectrometric detection techniques have been reported for achieving improved detection limits and taking advantage of the mass selectivity via quadrupole, triple quadrupole, ToF or Orbitrap detectors combined with a variety of different ionization techniques. While GC and CE enabled efficient separation of species, both appear restricted in sensitivity using UV or FID, respectively. In contrast, GC coupled with MS or NPD yielded satisfying detection limits. The main remaining disadvantage is the fact that $\mathrm{N}$-oxides are not sufficiently volatile, and have to be reduced prior to the analysis (i.e., via $\mathrm{Zn}$ powder in acidic solution, or by applying serdoxit Serdoxit columns). Finally, CE and MEKC methods were rarely applied to date in PA analysis. Concluding, as the current state-of-the-art in terms of both selectivity and sensitivity addressing these complex matrices with sufficient analytical quality, LC-MS/MS appears the recommended technique.

\section{Conclusions}

The phytopharmaceutical industry has been analyzing pyrrolizidine alkaloids in plant extracts for almost 30 years. To date, sensitive and selective analytical methods for determination of PAs in plant extracts have been developed and applied. Surprisingly, only few research groups dedicated efforts to the development of innovative, more efficient, and exhaustive extraction strategies. Hence, to date, usually the simplest or most readily established techniques for the respective plant are applied, albeit more efficient methods may be available. Only four out of thirteen plants were thoroughly investigated with regard to optimal extraction conditions or procedures. Even less attention has been paid to the fact that the trueness of the values reported during the analytical assessment of the PA content undoubtedly hinges on the quantitative extraction of PAs for avoiding that erroneous levels are reported.

In summary, this review shows that the extraction and analytical assessment of PAs in plant extracts has a long history, yet would benefit from further evolving strategies on both innovative efficient extraction schemes and advanced molecularly selective analytical quantification techniques ensuring the safety of herbal substances and herbal extracts.

Author Contributions: Conceptualization, T.K., M.A.-T., and B.M.; methodology, T.K., M.A.-T., and B.M.; writing—original draft preparation, T.K.; writing—review and editing, T.K., M.A.-T., and B.M.; supervision, B.M.; project administration, B.M.; and funding acquisition, T.K. All authors have read and agreed to the published version of the manuscript.

Funding: Funding of this project by AiF (Arbeitsgemeinschaft industrieller Forschung) is greatly acknowledged.

Acknowledgments: T.K. expresses his honest gratitude to Sebastian Jäger for his support and technical discussions during writing this review.

Conflicts of Interest: The authors declare no conflict of interest. The founding sponsors had no role in the design of the study; in the collection or interpretation of data; in the writing of the manuscript, and in the decision to publish the results 


\section{References}

1. Roeder, E. Medicinal plants in Europe containing pyrrolizidine alkaloids. Pharmazie 1995, 50, 83-93. [PubMed]

2. Analytik und Toxizität von Pyrrolizidinalkaloiden sowie eine Einschätzung des gesundheitlichen Risikos durch deren Vorkommen in Honig. Available online: https://www.bfr.bund.de/cm/343/analytik-undtoxizitaet-von-pyrrolizidinalkaloiden.pdf (accessed on 7 January 2019).

3. Schmeller, T.; El-Shazly, A.; Wink, M. Allelochemical activities of pyrrolizidine alkaloids: Interactions with neuroreceptors and acetylcholine related enzymes. J. Chem. Ecol. 1997, 23, 399-416. [CrossRef]

4. Rietjens, I.M.C.M.; Martena, M.J.; Boersma, M.G.; Spiegelenberg, W.; Alink, G.M. Molecular mechanisms of toxicity of important food-borne phytotoxins. Mol. Nutr. Food Res. 2005, 49, 131-158. [CrossRef]

5. Moreira, R.; Pereira, D.M.; Valentão, P.; Andrade, P.B. Pyrrolizidine alkaloids: Chemistry, pharmacology, toxicology and food safety. Int. J. Mol. Sci. 2018, 31, 1668. [CrossRef]

6. Benamar, H.; Tomassini, L.; Venditti, A.; Marouf, A.; Bennaceur, M.; Serafini, M.; Nicoletti, M. Acetylcholinesterase inhibitory activity of pyrrolizidine alkaloids from Echium. Confusum. Coincy. Nat. Prod. Res. 2017, 19, 1668. [CrossRef] [PubMed]

7. Colegate, S.M.; Gardner, D.R.; Betz, J.M.; Fischer, O.W.; Liede-Schumann, S.; Boppré, M. Pro-toxic 1,2-Dehydropyrrolizidine Alkaloid Esters, Including Unprecedented 10-Membered Macrocyclic Diesters, in the Medicinally-used Alafia cf. caudata and Amphineurion marginatum. Phytochem. Anal. 2016, 27, 257-276. [CrossRef] [PubMed]

8. Hartmann, T. Chemical ecology of pyrrolizidine alkaloids. Planta 1999, 207, 483-495. [CrossRef]

9. Mattocks, A.R. Toxicity of Pyrrolizidine Alkaloids. Nature 1968, 217, 723-728. [CrossRef]

10. Bush, L.P.; Fannin, F.F.; Siegel, M.R.; Dahlman, D.L.; Burton, H.R. Chemistry, occurrence and biological effects of saturated pyrrolizidine alkaloids associated with endophyte-grass interactions. Agric. Ecosyst. Environ. 1993, 44, 81-102. [CrossRef]

11. Bundesgesundheitsamt (German Federal Health Bureau). Bekanntmachung über die Zulassung und Registrierung von Arzneimitteln (abwehr von Arzneimittelrisiken Stufe 2). Bundesanzeiger 1992, 111, 4805.

12. Knutsen, H.K.; Alexander, J.; Barregård, L.; Bignami, M.; Brüschweiler, B.; Ceccatelli, S.; Cottrill, B.; Dinovi, M.; Edler, L.; Grasl-Kraupp, B. Risks for human health related to the presence of pyrrolizidine alkaloids in honey, tea, herbal infusions and food supplements. EFSA J. 2017, 15, 4908.

13. Aktualisierte Risikobewertung zu Gehalten an 1,2-ungesättigten Pyrrolizidinalkaloiden (PA) in Lebensmitteln. Available online: https:/www.bfr.bund.de/cm/343/aktualisierte-risikobewertung-zu-gehalten-an-1-2ungesaettigten-pyrrolizidinalkaloiden-pa-in-lebensmitteln.pdf (accessed on 19 April 2020).

14. El-Shazly, A.; El-Domiaty, M.; Witte, L.; Wink, M. Pyrrolizidine alkaloids in members of the Boraginaceae from Sinai (Egypt). Biochem. Syst. Ecol. 1998, 26, 619-636. [CrossRef]

15. Roeder, E.; Wiedenfeld, H.; Schraut, R. Pyrrolizidine alkaloids from Alkanna tinctoria. Phytochemistry 1984, 23, 2125-2126. [CrossRef]

16. Hendriks, H.; Bruins, A.P.; Huizing, H.J. Detection of Curassavine and some related pyrrolizidine alkaloids in an Anchusa officinalis strain by means of positive ion and negative ion chemical ionization GC/MS. Biol. Mass Spectrom. 1988, 17, 129-132. [CrossRef]

17. Larson, K.M.; Roby, M.R.; Stermitz, F.R. Unsaturated pyrrolizidines from borage (Borago officinalis), a common garden herb. J. Nat. Prod. 1984, 47, 747-748. [CrossRef]

18. Dodson, C.D.; Stermitz, F.R. Pyrrolizidine Alkaloids from Borage (Borago officinalis) Seeds and Flowers. J. Nat. Prod. 1986, 49, 727-728. [CrossRef]

19. Herrmann, M.; Joppe, H.; Schmaus, G. Thesinine-4'-O- $\beta$-D-glucoside the first glycosylated plant pyrrolizidine alkaloid from Borago officinalis. Phytochemistry 2002, 60, 399-402. [CrossRef]

20. Benn, M.; Gul, W. Pyrrolizidine alkaloids in the antipodean genus Brachyglottis (Asteraceae). Biochem. Syst. Ecol. 2007, 35, 676-681. [CrossRef]

21. Bai, Y.; Benn, M. The Alkaloids of Brachyglottis hectorii. Arkat USA 2006, 3, 34-42.

22. Tundis, R.; Loizzo, M.R.; Statti, G.A.; Passalacqua, N.G.; Peruzzi, L.; Menichini, F. Pyrrolizidine alkaloid profiles of the Senecio cineraria Group (Asteraceae). Z. Naturforsch. Sect. C J. Biosci. 2007, 62, 467-472. [CrossRef]

23. El-Shazly, A. Pyrrolizidine alkaloid profiles of some Senecio species from Egypt. Z. Naturforsch. Sect. C J. Biosci. 2002, 57, 429-433. [CrossRef] [PubMed] 
24. Wiedenfeld, H.; Montes, C.; Tawil, B.; Contin, A.; Wynsma, R. Pyrrolizidine alkaloid level in Senecio bicolor (Willd.) Tod, ssp. cineraria (DC.) from Middle Europe. Pharmazie 2006, 61, 559-561. [PubMed]

25. Damianakos, H.; Jeziorek, M.; Sykłowska-Baranek, K.; Buchwald, W.; Pietrosiuk, A.; Chinou, I. Pyrrolizidine alkaloids from Cynoglossum columnae Ten. (Boraginaceae). Phytochem. Lett. 2016, 15, 234-237. [CrossRef]

26. El-Shazly, A.; Sarg, T.; Ateya, A.; Abdel Aziz, E.; Witte, L.; Wink, M. Pyrrolizidine alkaloids of Cynoglossum officinale and Cynoglossum amabile (Family Boraginaceae). Biochem. Syst. Ecol. 1996, 24, 415-421. [CrossRef]

27. Furuya, T.; Hikichi, M. Lindelofine and supinine: Pyrrolizidine alkaloids from Eupatorium stoechadosmum. Phytochemistry 1973, 12, 225. [CrossRef]

28. Edgar, J.A.; Lin, H.J.; Kumana, C.R.; Ng, M.M. Pyrrolizidine alkaloid composition of three Chinese medicinal herbs, Eupatorium cannabinum, E. japonicum and Crotalaria assamica. Am. J. Chin. Med. 1992, 20, 281-288. [CrossRef] [PubMed]

29. Pedersen, E. Echinatine and supinine: Pyrrolizidine alkaloids from Eupatorium cannabinum. Phytochemistry 1975, 14, 2086-2087. [CrossRef]

30. Hendriks, H.; Malingré, T.M.; Elema, E.T. Pyrrolizidine alkaloids, flavonoids and volatile compounds in the genus Eupatorium-Eupatorium cannabinum L., an ancient drug with new perspectives. Pharm. Weekbl. Sci. Ed. 1983, 5, 281-286. [CrossRef]

31. Colegate, S.M.; Upton, R.; Gardner, D.R.; Panter, K.E.; Betz, J.M. Potentially toxic pyrrolizidine alkaloids in Eupatorium perfoliatum and three related species. Implications for herbal use as boneset. Phytochem. Anal. 2018, 29, 613-626. [CrossRef]

32. Kast, C.; Kilchenmann, V.; Reinhard, H.; Droz, B.; Lucchetti, M.A.; Dübecke, A.; Beckh, G.; Zoller, O. Chemical fingerprinting identifies Echium vulgare, Eupatorium cannabinum and Senecio spp. as plant species mainly responsible for pyrrolizidine alkaloids in bee-collected pollen. Food Addit. Contam. Part A Chem. Anal. Control. Expo. Risk Assess. 2018, 35, 316-327. [CrossRef]

33. Wiedenfeld, H.; Guerrero, R.; Roeder, E. Pyrrolizidine alkaloids from Eupatorium portoricense. Planta Med. 1995, 61, 380-381. [CrossRef] [PubMed]

34. Lang, G.; Passreiter, C.M.; Medinilla, B.; Castillo, J.J.; Witte, L. Non-toxic pyrrolizidine alkaloids from Eupatorium semialatum. Biochem. Syst. Ecol. 2001, 29, 143-147. [CrossRef]

35. Reina, M.; Gonzalez-Coloma, A.; Gutierrez, C.; Cabrera, R.; Henriquez, J.; Villarroel, L. Pyrrolizidine alkaloids from Heliotropium megalanthum. J. Nat. Prod. 1998, 61, 1418-1420. [CrossRef] [PubMed]

36. Davicino, J.G.; Pestchanker, M.J.; Giordano, O.S. Pyrrolizidine alkaloids from Heliotropium curassavicum. Phytochemistry 1988, 27, 960-962. [CrossRef]

37. Roeder, E.; Breitmaier, E.; Birecka, H.; Frohlicht, M.W.; Badzies-Crombach, A. Pyrrolizidine alkaloids of Heliotropium spathulatum. Phytochemistry 1991, 30, 1703-1706. [CrossRef]

38. Ravi, S.; Lakshmanan, A.J.; Herz, W. Iso-lycopsamine, a pyrrolizidine alkaloid from Heliotropium keralense. Phytochemistry 1990, 29, 361-364. [CrossRef]

39. Mohanraj, S.; Subramanian, P.S.; Herz, W. Minor alkaloids of Heliotropium curassavicum. Phytochemistry 1982, 21, 1775-1779. [CrossRef]

40. Farsam, H.; Yassa, N.; Sarkhail, P.; Shafiee, A. New pyrrolizidine alkaloids from Heliotropium crassifolium. Planta Med. 2000, 66, 389-391. [CrossRef]

41. Yassa, N.; Farsam, H.; Shafiee, A.; Rustaiyan, A. Pyrrolizidine alkaloids from Heliotropium esfandiarii. Planta Med. 1996, 62, 583-584. [CrossRef]

42. Shafiee, A.; Salimi, M.; Farsam, H.; Yassa, N. Pyrrolizidine alkaloids from Heliotropium dissitiflorum Boiss. Daru 2002, 10, 168-170.

43. Farrag, N.M.; Abdel-Aziz, E.M.; El-Shafae, A.M.; Ateya, A.M.; Domiaty, M.M. El Pyrrolizidine alkaloids of Heliotropium bacciferum Forssk from Egypt. Int. J. Pharmacogn. 1996, 34, 374-377. [CrossRef]

44. Zalkow, L.H.; Boxetti, S.; Gelbaum, L.; Gordon, M.; Patil, B.B.; Shaxi1, A.; Van Dbrveer, D. Pyrrolizidine Alkaloids from Middle Eastern Plants. J. Nat. Prod. 1979, 42, 603-614. [CrossRef]

45. O'Dowd, D.J.; Edgar, J.A. Seasonal dynamics in the pyrrolizidine alkaloids of Heliotropium europaeum. Aust. J. Ecol. 1989, 14, 95-105. [CrossRef]

46. Constantinidis, T.; Harvala, C.; Skaltsounis, A.L. Pyrrolizidine N-oxide alkaloids of Heliotropium hirsutissimum. Phytochemistry 1993, 32, 1335-1337. [CrossRef]

47. Lakshmanan, A.J.; Shanmugasundaram, S. Helibractinecine, a pyrrolizidine alkaloid from Heliotropium bracteatum. Phytochemistry 1994, 36, 245-248. [CrossRef] 
48. Mohanraj, S.; Kulanthaivel, P.; Subramanian, P.S.; Herz, W. Helifoline, a pyrrolizidine alkaloid from Heliotropium ovalifolium. Phytochemistry 1981, 20, 1991-1995. [CrossRef]

49. Lakshmanan, A.J.; Shanmugasundaram, S. Heliscabine, a pyrrolizidine ester alkaloid from Heliotropium scabrum. Phytochemistry 1995, 39, 473-475. [CrossRef]

50. Krenn, L.; Wiedenfeld, H.; Roeder, E. Pyrrolizidine alkaloids from Lithospermum officinale. Phytochemistry 1994, 37, 275-277. [CrossRef]

51. Wiedenfeld, H.; Pietrosiuk, A.; Furmanowa, M.; Roeder, E. Pyrrolizidine alkaloids from Lithospermum canescens Lehm. Z. Nat. Sect. C J. Biosci. 2003, 58, 173-176. [CrossRef]

52. Pietrosiuk, A.; Sykłowska-Baranek, K.; Wiedenfeld, H.; Wolinowska, R.; Furmanowa, M.; Jaroszyk, E. The shikonin derivatives and pyrrolizidine alkaloids in hairy root cultures of Lithospermum canescens (Michx.) Lehm. Plant Cell Rep. 2006, 25, 1052-1058. [CrossRef]

53. Roeder, E.; Rengel, B. Pyrrolizidine Alkaloids from Erythrorhzion. Phytochemistry 1990, $29,690-693$. [CrossRef]

54. Mroczek, T.; Glowniak, K.; Wlaszczyk, A. Simultaneous determination of N-oxides and free bases of pyrrolizidine alkaloids by cation-exchange solid-phase extraction and ion-pair high-performance liquid chromatography. J. Chromatogr. A 2002, 949, 249-262. [CrossRef]

55. Niwa, H.; Ishiwata, H.; Yamada, K. Separation and determination of macrocyclic pyrrolizidine alkaloids of the otonecine type present in the edible plant Petasites japonicus by reversed-phase high-performance liquid chromatography. J. Chromatogr. A 1983, 257, 146-150. [CrossRef]

56. Aydin, A.A.; Letzel, T. Simultaneous investigation of sesquiterpenes, pyrrolizidine alkaloids and N-oxides in Butterbur (Petasites hybridus) with an offline 2D-combination of HPLC-UV and LC-MMI-ToF-MS. J. Pharm. Biomed. Anal. 2013, 85, 74-82. [CrossRef]

57. Wildi, E.; Langer, T.; Schaffner, W.; Büter, K.B. Quantitative analysis of petasin and pyrrolizidine alkaloids in leaves and rhizomes of in situ grown Petasites hybridus plants. Planta Med. 1998, 64, 264-267. [CrossRef]

58. Langer, T.; Möstl, E.; Chizzola, R.; Gutleb, R. A competitive enzyme immunoassay for the pyrrolizidine alkaloids of the senecionine type. Planta Med. 1996, 62, 267-271. [CrossRef]

59. Chizzola, R.; Ozelsberger, B.; Langer, T. Variability in chemical constituents in Petasites hybridus from Austria. Biochem. Syst. Ecol. 2000, 28, 421-432. [CrossRef]

60. Segall, H.J. Reverse Phase Isolation of Pyrrolizidine Alkaloids. J. Liq. Chromatogr. 1979, 2, 429-436. [CrossRef]

61. Yang, X.; Yang, L.; Xiong, A.; Li, D.; Wang, Z. Authentication of Senecio scandens and S. vulgaris based on the comprehensive secondary metabolic patterns gained by UPLC-DAD/ESI-MS. J. Pharm. Biomed. Anal. 2011, 56, 165-172. [CrossRef]

62. Borstel, K.V.; Witte, L.; Hartmann, T. Pyrrolizidine alkaloid patterns in populations of Senecio vulgaris, S. vernalis and their hybrids. Phytochemistry 1989, 28, 1635-1638. [CrossRef]

63. Witte, L.; Ernst, L.; Adam, H.; Hartmannt, T. Chemotypes of two pyrrolizidine alkaloid-containing Senecio species. Phytochemistry 1992, 31, 559-565. [CrossRef]

64. Schaneberg, B.T.; Molyneux, R.J.; Khan, I.A. Evaporative light scattering detection of pyrrolizidine alkaloids. Phytochem. Anal. 2004, 15, 36-39. [CrossRef]

65. Zhou, Y.; Li, N.; Choi, F.F.K.; Qiao, C.F.; Song, J.Z.; Li, S.L.; Liu, X.; Cai, Z.W.; Fu, P.P.; Lin, G.; et al. A new approach for simultaneous screening and quantification of toxic pyrrolizidine alkaloids in some potential pyrrolizidine alkaloid-containing plants by using ultra performance liquid chromatography-tandem quadrupole mass spectrometry. Anal. Chim. Acta 2010, 681, 33-40. [CrossRef]

66. Cheng, D.; Nguyen, V.-T.; Ndihokubwayo, N.; Ge, J.; Mulder, P.P.J. Pyrrolizidine alkaloid variation in Senecio vulgaris populations from native and invasive ranges. PeerJ 2017, 5, e3686. [CrossRef]

67. Segall, H.J. Preparative isolation of pyrrolizidine alkaloids derived from senecio vulgaris. J. Liq. Chromatogr. 1979, 2, 1319-1323. [CrossRef]

68. Pelser, P.B.; De Vos, H.; Theuring, C.; Beuerle, T.; Vrieling, K.; Hartmann, T. Frequent gain and loss of pyrrolizidine alkaloids in the evolution of Senecio section Jacobaea (Asteraceae). Phytochemistry 2005, 66, 1285-1295. [CrossRef]

69. Pestchanker, M.J.; Giordano, O.S. Pyrrolizidine Alkaloids from Five Senecio Species. J. Nat. Prod. 1986, 49, 722-723. [CrossRef] 
70. Pieters, L.A.C.; Vlietinck, A.J. Quantitative ${ }^{1} \mathrm{~h}$ fourier transform nuclear magnetic resonance spectroscopic analysis of mixtures of pyrrolizidine alkaloids from Senecio vulgaris. Fresenius Z. für Anal. Chem. 1985, 321, 355-358. [CrossRef]

71. Bicchi, C.; Rubiolo, P.; Frattini, C. Capillary gas chromatography-fourier transform infrared spectroscopy of pyrrolizidine alkaloids of Senecio inaequidens DC. J. Chromatogr. A 1989, 473, 161-170. [CrossRef]

72. Hartmann, T.; Toppel, G. Senecionine n-oxide, the primary product of pyrrolizidine alkaloid biosynthesis in root cultures of Senecio vulgaris. Phytochemistry 1987, 26, 1639-1643. [CrossRef]

73. Gardner, D.R.; Thorne, M.S.; Molyneux, R.J.; Pfister, J.A.; Seawright, A.A. Pyrrolizidine alkaloids in Senecio madagascariensis from Australia and Hawaii and assessment of possible livestock poisoning. Biochem. Syst. Ecol. 2006, 34, 736-744. [CrossRef]

74. Krebs, H.C.; Carl, T.; Habermehl, G.G. Pyrrolizidine alkaloid composition in six Brazilian Senecio species. Phytochemistry 1996, 43, 1227-1229. [CrossRef]

75. Christov, V.; Evstatieva, L. Alkaloid profile of Bulgarian species from genus Senecio L. Z. Naturforsch. Sect. C J. Biosci. 2003, 58, 300-302. [CrossRef] [PubMed]

76. Bicchi, C.; D'Amato, A.; Cappelletti, E. Determination of pyrrolizidine alkaloids in senecio inaequidens D.C. by capillary gas chromatography. J. Chromatogr. A 1985, 349, 23-29. [CrossRef]

77. Bicchi, C.; Caniato, R.; Tabacchi, R.; Tsoupras, G. Capillary gas chromatography/positive and negative ion chemical ionization mass spectrometry on pyrrolizidine alkaloids of Senecio inaequidens using ammonia and hydroxyl ions as the reagent species. J. Nat. Prod. 1989, 52, 32-41.

78. Bicchi, C.; Rubiolo, P.; Frattini, C.; Sandra, P.; David, F. Off-Line supercritical fluid extraction and capillary gas chromatography of pyrrolidine alkaloids in Senecio species. J. Nat. Prod. 1991, 54, 941-945. [CrossRef]

79. Zalkow, L.H.; Asibal, C.F.; Glinski, J.A.; Bonetti, S.J.; Gelbaum, L.T.; Vanderveer, D.; Powis, G. Macrocyclic pyrrolizidine alkaloids from Senecio anonymus. separation of a complex alkaloid extract using droplet counter-current chromatography. J. Nat. Prod. 1988, 51, 690-702. [CrossRef]

80. Pieters, L.A.; Hartmann, T.; Janssens, J.; Vlietinck, A.J. Comparison of capillary gas chromatography with1H and13C nuclear magnetic resonance spectroscopy for the quantitation of pyrrolizidine alkaloids from Senecio vernalis. J. Chromatogr. A 1989, 462, 387-391. [CrossRef]

81. Parker, C.E.; Verma, S.; Tomer, K.B.; Reed, R.L.; Buhler, D.R. Determination of Senecio Alkaloids by thermospray liquid chromatography/mass spectrometry. Biol. Mass Spectrom. 1990, 19, 1-12. [CrossRef]

82. Yaber Grass, M.A.; Leicach, S.R. Changes in Senecio grisebachii pyrrolizidine alkaloids abundances and profiles as response to soil quality. J. Plant Interact. 2012, 7, 175-182. [CrossRef]

83. Kostova, N.; Christov, V.; Cholakova, M.; Nikolova, E.; Evstatieva, L. Pyrrolizidine alkaloids from Bulgarian species of the genus Senecio. J. Serb. Chem. Soc. 2006, 71, 1275-1280. [CrossRef]

84. Ray, A.C.; Williams, H.J.; Reagor, J.C. Pyrrolizidine alkaloids from Senecio longilobus and Senecio glabellus. Phytochemistry 1987, 26, 2431-2433. [CrossRef]

85. Pestchanker, M.J.; Ascheri, M.S.; Giordano, O.S. Uspallatine, a pyrrolizidine alkaloid from senecio uspallatensis. Phytochemistry 1985, 24, 1622-1624. [CrossRef]

86. Qualls, C.W.; Segall, H.J. Rapid isolation and identification of pyrrolizidine alkaloids (senecio vulgaris) by use of high-performance liquid chromatography. J. Chromatogr. A 1978, 150, 202-206. [CrossRef]

87. Macel, M.; Vrieling, K.; Klinkhamer, P.G.L. Variation in pyrrolizidine alkaloid patterns of Senecio jacobaea. Phytochemistry 2004, 65, 865-873. [CrossRef]

88. Noorwala, M.; Mohammad, F.V.; Ahmad, V.U.; Sener, B.; Ergun, F.; Deliorman, D. Pyrrolizidine alkaloids from Senecio lorenthii. Fitoterapia 2000, 71, 618-620. [CrossRef]

89. Roeder, E.; Bourauel, T. Pyrrolizidine alkaloids from Senecio leucanthemifolius and Senecio rodriguezii. Nat. Toxins 1993, 1, 241-245. [CrossRef]

90. Liddell, J.R.; Logie, C.G. A re-investigation of the alkaloids of Senecio pterophorus. Phytochemistry 1993, 34, 1629-1631. [CrossRef]

91. Segall, H.J.; Krick, T.P. Pyrrolizidine alkaloids: Organohalogen derivative isolated from Senecio jacobaea (Tansy Ragwort). Toxicol. Lett. 1979, 4, 193-198. [CrossRef]

92. Tinney, G.; Theuring, C.; Paul, N.; Hartmann, T. Effects of rust infection with Puccinia lagenophorae on pyrrolizidine alkaloids in Senecio vulgaris. Phytochemistry 1998, 49, 1589-1592. [CrossRef]

93. Chizzola, R. Rapid sample preparation technique for the determination of pyrrolizidine alkaloids in plant extracts. J. Chromatogr. A 1994, 668, 427-433. [CrossRef] 
94. Kirk, H.; Vrieling, K.; van der Meijden, E.; Klinkhamer, P.G.L. Species by environment interactions affect pyrrolizidine alkaloid expression in Senecio jacobaea, Senecio aquaticus, and their hybrids. J. Chem. Ecol. 2010, 36, 378-387. [CrossRef] [PubMed]

95. Hol, W.H.G.; Vrieling, K.; Van Veen, J.A. Nutrients decrease pyrrolizidine alkaloid concentrations in Senecio jacobaea. New Phytol. 2003, 158, 175-181. [CrossRef]

96. Crews, C.; Driffield, M.; Berthiller, F.; Krska, R. Loss of pyrrolizidine alkaloids on decomposition of ragwort (Senecio jacobaea) as measured by LC-TOF-MS. J. Agric. Food Chem. 2009, 57, 3669-3673. [CrossRef]

97. Mandic, B.; Godjevac, D.; Beskoski, V.; Simic, M.; Trifunovic, S.; Tesevic, V.; Vajs, V.; Milosavljevic, S. Pyrrolizidine alkaloids from seven wild-growing Senecio species in Serbia and Montenegro. J. Serb. Chem. Soc. 2009, 74, 27-34. [CrossRef]

98. Bohlmann, F.; Zdero, C.; Jakupovic, J.; Grenz, M.; Castro, V.; Kino, R.M.; Robinson, H.; Vincent, L.P.D. Further pyrrolizidine alkaloids and furoeremophilanes from Senecio species. Phytochemistry 1986, 25, 1151-1159. [CrossRef]

99. Lüthy, J.; Zweifel, U.; Karlhuber, B.; Schlatter, C. Pyrrolizidine Alkaloids of Senecio alpinus L. and Their Detection in Feedingstuffs. J. Agric. Food Chem. 1981, 29, 302-305. [CrossRef]

100. Steixjes, M.E.; Kelley, R.B.; Molyneux, R.J.; Seiber, J.N. Gc-Ms determination of pyrrolizidine alkaloids in four senecio species. J. Nat. Prod. 1991, 54, 759-773.

101. Kapadia, G.J.; Ramdass, A.; Bada, F. Pyrrolizidine alkaloids of Senecio glabellus. Pharm. Biol. 1990, 28 , 67-71. [CrossRef]

102. Vásquez, L.R.; Artiles, M.R.; Coloma, A.G.; Pérez, R.C.; Mesia, L.R. Pyrrolizidine alkaloids of Senecio sp from Peru. Quim. Nova 2011, 29, 67-71.

103. Suau, R.; Cabezudo, B.; Rico, R.; Nájera, F.; López-Romero, J.M.; García, A.I. Pyrrolizidine alkaloids from three Spanish Senecio species. Biochem. Syst. Ecol. 2002, 30, 981-984. [CrossRef]

104. Zhang, F.; Wang, C.H.; Wang, W.; Chen, L.X.; Ma, H.Y.; Zhang, C.F.; Zhang, M.; Bligh, S.W.A.; Wang, Z.T. Quantitative analysis by HPLC-MS2of the Pyrrolizidine alkaloid adonifoline in Senecio scandens. Phytochem. Anal. 2008, 19, 25-31. [CrossRef]

105. Dong-Liang, C.; Jin-Kui, N.; Roeder, E. Pyrrolizidine alkaloids from Senecio kaschkarovii. Phytochemistry 1992, 31, 3671-3672. [CrossRef]

106. Asada, Y.; Furuya, T.; Shiro, M.; Nakai, H. Senecicannabine, a new pyrrolizidine alkaloid from Senecio cannabifolius. Tetrahedron Lett. 1982, 23, 189-192. [CrossRef]

107. Were, O.; Benn, M.; Munavu, R.M. The pyrrolizidine alkaloids of Senecio syringifolius and S. hadiensis from Kenya. Phytochemistry 1993, 32, 1595-1602. [CrossRef]

108. Porter, L.A.; Geissman, T.A. Angularine, a New Pyrrolizidine Alkaloid from Senecio angulatus L. J. Org. Chem. 1962, 27, 4132-4134. [CrossRef]

109. Benn, M.; Were, O. Ruwenine and ruzorine: Pyrrolizidine alkaloids of Senecio ruwenzoriensis. Phytochemistry 1992, 31, 3295-3296. [CrossRef]

110. Röder, E.; Wiedenfeld, H.; Pfitzer, A. Doriasenine, a pyrrolizidine alkaloid from Senecio doria. Phytochemistry 1988, 27, 4000-4001. [CrossRef]

111. Bredenkamp, M.W.; Wiechers, A.; van Rooyen, P.H. A new pyrrolizidine alkaloid N-oxide and the revised structure of sceleratine. Tetrahedron Lett. 1985, 26, 5721-5724. [CrossRef]

112. Furuya, T.; Hikichi, M. Alkaloids and triterpenoids of Symphytum officinale. Phytochemistry 1971, 10, $2217-2220$. [CrossRef]

113. Kim, N.C.; Oberlies, N.H.; Brine, D.R.; Handy, R.W.; Wani, M.C.; Wall, M.E. Isolation of symlandine from the roots of common comfrey (Symphytum officinale) using countercurrent chromatography. J. Nat. Prod. 2001, 64, 251-253. [CrossRef]

114. Couet, C.E.; Crews, C.; Hanley, A.B. Analysis, separation, and bioassay of pyrrolizidine alkaloids from comfrey (Symphytum officinale). Nat. Toxins 1996, 4, 163-167. [CrossRef]

115. Mossoba, M.M.; Lin, H.S.; Andrzejewski, D.; Sphon, J.A.; Betz, J.M.; Miller, L.J.; Eppley, R.M.; Trucksess, M.W.; Page, S.W. Application of Gas-Chromatography Matrix-Isolation Fourier-Transform Infrared-Spectroscopy to the Identification of Pyrrolizidine Alkaloids from Comfrey Root (Symphytum-officinale L.). J. AOAC Int. 1994, 60, 945-948. [CrossRef] 
116. Liu, F.; Wan, S.Y.; Jiang, Z.; Li, S.F.Y.; Ong, E.S.; Osorio, J.C.C. Determination of pyrrolizidine alkaloids in comfrey by liquid chromatography-electrospray ionization mass spectrometry. Talanta 2009, 80, 916-932. [CrossRef]

117. Smyrska-Wieleba, N.; Wojtanowski, K.K.; Mroczek, T. Comparative HILIC/ESI-QTOF-MS and HPTLC studies of pyrrolizidine alkaloids in flowers of Tussilago farfara and roots of Arnebia euchroma. Phytochem. Lett. 2017, 20, 339-349. [CrossRef]

118. Lebada, R.; Schreier, A.; Scherz, S.; Resch, C.; Krenn, L.; Kopp, B. Quantitative analysis of the pyrrolizidine alkaloids senkirkine and senecionine in Tussilago farfara L. by capillary electrophoresis. Phytochem. Anal. 2000, 11, 336-339. [CrossRef]

119. Adamczak, A.; Opala, B.; Gryszczyńska, A.; Buchwald, W. Content of pyrrolizidine alkaloids in the leaves of coltsfoot (Tussilago farfara L.) in Poland. Acta Soc. Bot. Pol. 2013, 82, 289-293. [CrossRef]

120. Nedelcheva, A.; Kostova, N.; Sidjimov, A. Pyrrolizidine alkaloids in Tussilago farfara from Bulgaria. Biotechnol. Biotechnol. Equip. 2015, 29, 1-7. [CrossRef]

121. Cao, K.; Xu, Y.; Mu, X.; Zhang, Q.; Wang, R.; Lv, J. Sensitive determination of pyrrolizidine alkaloids in Tussilago farfara L. by field-amplified, sample-stacking, sweeping micellar electrokinetic chromatography. J. Sep. Sci. 2016, 39, 4243-4250. [CrossRef]

122. Kopp, T.; Salzer, L.; Abdel-Tawab, M.; Mizaikoff, B. Efficient Extraction of Pyrrolizidine Alkaloids from Plants by Pressurised Liquid Extraction-A Preliminary Study. Planta Med. 2019, 86, 85-90. [CrossRef]

123. Siciliano, T.; De Leo, M.; Bader, A.; De Tommasi, N.; Vrieling, K.; Braca, A.; Morelli, I. Pyrrolizidine alkaloids from Anchusa strigosa and their antifeedant activity. Phytochemistry 2005, 66, 1593-1600. [CrossRef] [PubMed]

124. Braca, A.; Bader, A.; Siciliano, T.; Morelli, I.; De Tommasi, N. New Pyrrolizidine Alkaloids and Glycosides from Anchusa strigosa. Planta Med. 2003, 69, 835-841. [PubMed]

125. These, A.; Bodi, D.; Ronczka, S.; Lahrssen-Wiederholt, M.; Preiss-Weigert, A. Structural screening by multiple reaction monitoring as a new approach for tandem mass spectrometry: Presented for the determination of pyrrolizidine alkaloids in plants. Anal. Bioanal. Chem. 2013, 405, 9375-9383. [CrossRef]

126. Vacillotto, G.; Favretto, D.; Seraglia, R.; Pagiotti, R.; Traldi, P.; Mattoli, L. A rapid and highly specific method to evaluate the presence of pyrrolizidine alkaloids in Borago officinalis seed oil. J. Mass Spectrom. 2013, 48, 1078-1082. [CrossRef]

127. Van Dam, N.M.; Verpoorte, R.; van der Meijden, E. Extreme differences in pyrrolizidine alkaloid levels between leaves of Cynoglossum officinale. Phytochemistry 1994, 37, 1013-1016. [CrossRef]

128. Van Dam, N.M.; van der Meijden, E.; Verpoorte, R. Induced responses in three alkaloid-containing plant species. Oecologia 1993, 95, 425-430. [CrossRef]

129. Van Dam, N.M.; Witte, L.; Theuring, C.; Hartmann, T. Distribution, biosynthesis and turnover of pyrrolizidine alkaloids in Cynoglossum officinale. Phytochemistry 1995, 39, 287-292. [CrossRef]

130. Pfister, J.A.; Molyneux, R.J.; Baker, D.C. Pyrrolizidine Alkaloid content of Houndstongue (Cynoglossum officinale L.). J. Range Manag. 1992, 45, 254-256. [CrossRef]

131. Mroczek, T.; Baj, S.; Chrobok, A.; Glowniak, K. Screening for pyrrolizidine alkaloids in plant materials by electron ionization RP-HPLC-MS with thermabeam interface. Biomed. Chromatogr. 2004, 18, 744-751. [CrossRef]

132. Zalkow, L.H.; Gelbaum, L.; Keinan, E. Isolation of the pyrrolizidine alkaloid europine N-oxide from heliotropium maris-mortui and H. rotundifolium. Phytochemistry 1978, 17, 172. [CrossRef]

133. Reina, M.; Gonzalez-Coloma, A.; Gutierrez, C.; Cabrera, R.; Henriquez, J.; Villarroel, L. Bioactive saturated pyrrolizidine alkaloids from Heliotropium floridum. Phytochemistry 1997, 46, 845-853. [CrossRef]

134. Souza, J.S.N.; Machado, L.L.; Pessoa, O.D.L.; Braz-Filho, R.; Overk, C.R.; Yao, P.; Cordell, G.A.; Lemos, T.L.G. Pyrrolizidine alkaloids from Heliotropium indicum. J. Braz. Chem. Soc. 2005, 16, 140-1414. [CrossRef]

135. Birecka, H.; DiNolfo, T.E.; Martin, W.B.; Frohlich, M.W. Polyamines and leaf senescence in pyrrolizidine alkaloid-bearing Heliotropium plants. Phytochemistry 1984, 23, 991-997. [CrossRef]

136. Lakshmanan, A.J.; Shanmugasundaram, S. Ester alkaloids of Heliotropium bracteatum. Phytochemistry 1995, 40, 291-294. [CrossRef]

137. Birecka, H.; Frohlich, M.W.; Hull, L.; Chaskes, M.J. Pyrrolizidine alkaloids of Heliotropium from Mexico and adjacent U.S.A. Phytochemistry 1980, 19, 421-426. [CrossRef] 
138. Schenk, A.; Siewert, B.; Toff, S.; Drewe, J. UPLC TOF MS for sensitive quantification of naturally occurring pyrrolizidine alkaloids in Petasites hybridus extract (Ze 339). J. Chromatogr. B Anal. Technol. Biomed. Life Sci. 2015, 997, 23-29. [CrossRef]

139. Knez, Z.; Hadolin, M.; Debrunner, B. Separation of pyrrolizidine alkaloids from Petasites hybridus with high pressure n-propane extraction. Chem. Tech. 1999, 51, 141-143.

140. Zhang, F.; Wang, C.H.; Xiong, A.Z.; Wang, W.; Yang, L.; Branford-White, C.J.; Wang, Z.T.; Bligh, S.W.A. Quantitative analysis of total retronecine esters-type pyrrolizidine alkaloids in plant by high performance liquid chromatography. Anal. Chim. Acta 2007, 19, 25-31. [CrossRef]

141. Lee, S.T.; Schoch, T.K.; Stegelmeier, B.L.; Gardner, D.R.; Than, K.A.; Molyneux, R.J. Development of enzyme-linked immunosorbent assays for the hepatotoxic alkaloids riddelliine and riddelliine $\mathrm{N}$-oxide. J. Agric. Food Chem. 2001, 49, 4144-4151. [CrossRef]

142. Cheng, D.L.; Niu, J.K.; Roeder, E. Pyrrolizidine Alkaloids from Senecio-Kaschkarovii. Phytochemistry 1992, 31, 3671-3672.

143. Perez-Castorena, A.L.; Arciniegas, A.; Castro, A.; Villasenor, J.L.; Toscano, R.A.; De Vivar, A.R. Pyrrolizidine alkaloids from Senecio roseus and Senecio helodes. J. Nat. Prod. 1997, 60, 1322-1325. [CrossRef]

144. Bai, Y.; Benn, M.; Majak, W. Pyrrolizidine alkaloids of three species of Senecio in British Columbia. Planta Med. 1996, 62, 71-72. [CrossRef] [PubMed]

145. Benn, M.H.; Mathenge, S.; Munavu, R.M.; Were, S.O. The principal alkaloid of Senecio schweinfurthii. Phytochemistry 1995, 40, 1327-1329. [CrossRef]

146. Urones, J.G.; Barcala, P.B.; Marcos, I.S.; Moro, R.F.; Esteban, M.L.; Rodriguez, A.F. Pyrrolizidine alkaloids from Senecio gallicus and S. Adonidifolius. Phytochemistry 1988, 27, 1507-1510. [CrossRef]

147. Dimenna, G.P.; Krick, T.P.; Segall, H.J. Rapid high-performance liquid chromatography isolation of monoesters, diesters and macrocyclic diester pyrrolizidine alkaloids from Senecio jacobaea and Amsinckia intermedia. J. Chromatogr. A 1980, 192, 474-478. [CrossRef]

148. Roeder, E.; Wiedenfeld, H.; Britz-Kirstgen, R. Pyrrolizidine alkaloids from Senecio cacaliaster. Phytochemistry 1984, 23, 1761-1763. [CrossRef]

149. Molyneux, R.J.; Earl Johnson, A. Extraordinary levels of production of pyrrolizidine alkaloids in senecio riddellii. J. Nat. Prod. 1984, 47, 1030-1032. [CrossRef]

150. Ndjoko, K.; Wolfender, J.L.; Röder, E.; Hostettmann, K. Determination of pyrrolizidine alkaloids in Senecio species by liquid chromatography/thermospray-mass spectrometry and liquid chromatography/nuclear magnetic resonance spectroscopy. Planta Med. 1999, 65, 562-566. [CrossRef]

151. Ramsdell, H.S.; Buhler, D.R. High-performance liquid chromatographic analysis of pyrrolizidine (Senecio) alkaloids using a reversed-phase styrene-divinylbenzence resin column. J. Chromatogr. A 1981, 210, 154-158. [CrossRef]

152. Mroczek, T.; Widelski, J.; Gowniak, K. Optimization of Extraction of Pyrrolizidine Alkaloids from Plant Material. Chem. Anal. 2006, 51,567-580.

153. Stegemann, T.; Kruse, L.H.; Brütt, M.; Ober, D. Specific Distribution of Pyrrolizidine Alkaloids in Floral Parts of Comfrey (Symphytum officinale) and its Implications for Flower Ecology. J. Chem. Ecol. 2018, 45, 128-135. [CrossRef] [PubMed]

154. Oberlies, N.H.; Kim, N.-C.; Brine, D.R.; Collins, B.J.; Handy, R.W.; Sparacino, C.M.; Wani, M.C.; Wall, M.E. Analysis of herbal teas made from the leaves of comfrey (Symphytum officinale): Reduction of N-oxides results in order of magnitude increases in the measurable concentration of pyrrolizidine alkaloids. Public Health Nutr. 2004, 7, 919-924. [CrossRef] [PubMed]

155. O'Keeffe, C.M.; Stutte, G.W.; McKeon-Bennett, M. Ragwort: Invasive weed and potential pharmaceutical. Hortic. Rev. (Am. Soc. Hortic. Sci.) 2015, 43, 145-183.

156. Culvenor, C.C.J.; Edgar, J.A.; Smith, L.W.; Hirono, I. The occurrence of senkirkine in Tussilago farfara. Aust. J. Chem. 1976, 29, 229-230. [CrossRef]

157. Jiang, Z.; Liu, F.; Goh, J.J.L.; Yu, L.; Li, S.F.Y.; Ong, E.S.; Ong, C.N. Determination of senkirkine and senecionine in Tussilago farfara using microwave-assisted extraction and pressurized hot water extraction with liquid chromatography tandem mass spectrometry. Talanta 2009, 79, 539-546. [CrossRef] [PubMed]

158. Mattocks, A.R.; Pigott, C.D. Pyrrolizidine alkaloids from Cynoglossum germanicum. Phytochemistry 1990, 29, 2871-2872. [CrossRef] 
159. Hendriks, H.; Balraadjsing, W.; Huizing, H.J.; Bruins, A.P. Investigation into the presence of pyrrolizidine alkaloids in Eupatorium cannabinum by means of positive and negative ion chemical ionization GC-MS. Planta Med. 1987, 53, 456-461. [CrossRef]

160. Tosun, F.; Tamer, U. Determination of pyrrolizidine alkaloids in the seeds of Heliotropium europaeum by GC-MS. Ankara Univ. Eczac. Fak. Derg. 2004, 33, 7-9.

161. Avula, B.; Wang, Y.H.; Wang, M.; Smillie, T.J.; Khan, I.A. Simultaneous determination of sesquiterpenes and pyrrolizidine alkaloids from the rhizomes of Petasites hybridus (L.) G.M. et Sch. and dietary supplements using UPLC-UV and HPLC-TOF-MS methods. J. Pharm. Biomed. Anal. 2012, 70, 53-63. [CrossRef]

162. Sener, B.; Ergun, F. Pyrrolizidine alkaloids from Petasites hybridus (L.) Gaertner. Gazi Univ. Eczac. Fak. Derg. 1996, 13, 171-173.

163. Roseman, D.M.; Wu, X.; Bober, M.; Miller, R.B.; Kurth, M.J.; Milco, L.A. Development of a Class-Specific Competitive Enzyme-Linked Immunosorbent Assay for the Detection of Pyrrolizidine Alkaloids in Vitro. J. Agric. Food Chem. 1992, 40, 1008-1014. [CrossRef]

164. Bober, M.A.; Kurth, M.J.; Milco, L.A.; Roseman, D.M.; Miller, R.B.; Segal, H.J. A Pyrrolizidine Alkaloid Enzyme-Linjed-Immunosorbent-Assay Detection Strategy. Acs Symp. Ser. 1991, 451, 176-183.

165. Roeder, E.; Pflueger, T. Analysis of pyrrolizidine alkaloids: A competitive enzyme-linked immunoassay (ELISA) for the quantitative determination of some toxic pyrrolizidine alkaloids. Nat. Toxins 1995, 3, 305-309. [CrossRef] [PubMed]

166. Pieters, L.A.C.; Vlietinck, A.J. Comparison of high-performance liquid chromatography with1H nuclear magnetic resonance spectrometry for the quantitative analysis of pyrrolizidine alkaloids from Senecio vulgaris. J. Liq. Chromatogr. 1986, 9, 745-755. [CrossRef]

167. Pieters, L.A.C.; Vlietinck, A.J. Quantitative analysis of pyrrolizidine alkaloid mixtures from Senecio vulgaris by carbon-13 nuclear magnetic resonance spectroscopy. Magn. Reson. Chem. 1987, 25, 8-10. [CrossRef]

168. Janeš, D.; Kreft, S. TLC densitometric method for screening of lycopsamine in comfrey root (Symphytum officinale L.) extracts using retrorsine as a reference compound. Acta Pharm. 2014, 64, 503-508. [CrossRef]

169. Roeder, E.; Liu, K.; Mutterlein, R. Quantitative Photometric-Determination of Pyrrolizidine Alkaloids in Symphyti Radix. Fresenius J. Anal. Chem. 1992, 343, 621-624. [CrossRef]

170. Adamczak, A.; Opala, B.; Gryszczyńska, A.; Buchwald, W. Acta Societatis Botanicorum Poloniae; Polish Botanical Society: Warsaw, Poland, 2013; ISBN 0163-7827 0163-782.

171. Kopp, T.; Abdel-Tawab, M.; Khoeiklang, M.; Mizaikoff, B. Development of a Selective Adsorbing Material for Binding of Pyrrolizidine Alkaloids in Herbal Extracts, Based on Molecular Group Imprinting. Planta Med. 2019, 85, 1107-1113. [CrossRef]

172. Alwahibi, M.S.; Perveen, K. Chemical analysis by GC-MS and in vitro antibacterial activity of Alkanna tinctoria extracts against skin infection causing bacteria. Biomed. Res. 2017, 28, 7946-7949.

173. Altundag, E.; Ozturk, M. Ethnomedicinal studies on the plant resources of east Anatolia, Turkey. Proc. Soc. Behav. Sci. 2011, 19, 756-777. [CrossRef]

174. Baharvand-Ahmadi, B.; Bahmani, M.; Tajeddini, P.; Rafieian-Kopaei, M.; Naghdi, N. An ethnobotanical study of medicinal plants administered for the treatment of hypertension. J. Ren. Inj. Prev. 2016, 5, 123-128. [CrossRef] [PubMed]

175. Leos-Rivas, C.; Verde-Star, M.J.; Torres, L.O.; Oranday-Cardenas, A.; Rivas-Morales, C.; Barron-Gonzalez, M.P.; Morales-Vallarta, M.R.; Cruz-Vega, D.E. In vitro Amoebicidal Activity of Borage (Borago officinalis) Extract on Entamoeba histolytica. J. Med. Food 2011, 14, 7-8. [CrossRef] [PubMed]

176. Thanina, A.C.; Karim, A.; Mourad, B. Phytochemical screening of Algerian Borago officinalis L. And evaluation of its antioxidant and antimicrobial activities against respiratory pathogens. Int. J. Phytomed. 2014, 26, 110-128.

177. Andrea, A.; Carmita, J.-J.; Diana, S.M.; Haydelba, D. Analysis of antimicrobial effect of twelve medicinal plants of ancient use in Ecuador. Cienc. UNEMI 2016, 9, 11-18.

178. Choi, H.J.; Song, J.H.; Kwon, D.H.; Baek, S.H. Antiviral and anticancer activities of 13(E)-labd-13-ene-8 $\alpha$, 15-diol isolated from Brachyglottis monroi. Phyther. Res. 2010, 24, 169-174.

179. Yook, C.N.; Na, Y.S.; Choi, H.J.; You, I.S.; Baek, J.M.; Baek, S.H. Antifungal effect of brachyglottis repanda ethanol extract. Toxicol. Res. 2013, 26, 117-121. [CrossRef]

180. Kim, J.I.; Choi, H.J.; Lee, J.S. Anticancer and antimicrobial activities of 13(E)-labd-13-ene-8 $\alpha$,15-diol from Brachyglottis monroi. J. Appl. Biol. Chem. 2013, 56, 49-51. [CrossRef] 
181. De Boer, H.J.; Kool, A.; Broberg, A.; Mziray, W.R.; Hedberg, I.; Levenfors, J.J. Anti-fungal and anti-bacterial activity of some herbal remedies from Tanzania. J. Ethnopharmacol. 2005, 96, 461-469. [CrossRef]

182. Selvi, F.; Coppi, A.; Cecchi, L. High epizoochorous specialization and low DNA sequence divergence in mediterranean cynoglossum (Boraginaceae): Evidence from fruit traits and ITS region. Taxon 2011, 60, 969-985. [CrossRef]

183. Hilger, H.H.; Greuter, W.; Stier, V. Taxa and names in Cynoglossum sensu lato (Boraginaceae, Cynoglosseae): An annotated, synonymic inventory, with links to the protologues and mention of original material. Biodivers. Data J. 2015, 3, e4831. [CrossRef]

184. Giday, M.; Teklehaymanot, T.; Animut, A.; Mekonnen, Y. Medicinal plants of the Shinasha, Agew-awi and Amhara peoples in northwest Ethiopia. J. Ethnopharmacol. 2007, 110, 516-525. [CrossRef] [PubMed]

185. Qwarse, M.; Sempombe, J.; Mihale, M.J.; Henry, L.; Mugoyela, V.; Sung, F.; Salaam, D. Cytotoxicity, Antibacterial and Antifungal Activities of Five Plant Species used by Agro-Pastoral Communities in Mbulu District, Tanzania. Int. J. Res. Pharm. Chem. 2017, 7, 1-14.

186. Jeziorek, M.; Damianakos, H.; Pietrosiuk, A.; Kawiak, A. Cytotoxic and antimicrobial activity of Cynoglossum columnae Ten. in vitro roots. Planta Med. 2012, 78, 371. [CrossRef]

187. Boyko, N.N.; Zaytsev, A.I.; Osolodchenko, T.P. Screening of antimicrobial activity of ethanolic extracts from raw materials containing alkaloids. J. Chem. Pharm. Res. 2015, 7, 160-166.

188. Anitha, M.; Daffodil, E.D.; Muthukumarasamy, S.; Mohan, V.R. Hepatoprotective and antioxidant activity of ethanol extract of Cynoglossum zeylanicum (vahl ex hornem) thurnb ex lehm in CCl4treated rats. J. Appl. Pharm. Sci. 2012, 3, 25-27.

189. Mattocks, A.R. Spectrophotometric Determination of Unsaturated Pyrrolizidine Alkaloids. Anal. Chem. 1967, 39, 443-447. [CrossRef]

190. El-Seedi, H.R.; Sata, N.; Torssell, K.B.G.; Nishiyama, S. New labdene diterpenes from Eupatorium glutinosum. J. Nat. Prod. 2002, 65, 728-729. [CrossRef]

191. Urzua, A.; Caroli, M.; Vasquez, L.; Mendoza, L.; Wilkens, M.; Tojo, E. Antimicrobial study of the resinous exudate and of diterpenoids isolated from Eupatorium salvia (Asteraceae). J. Ethnopharmacol. 1998, 62, 251-254. [CrossRef]

192. Sirinthipaporn, A.; Jiraungkoorskul, W. Wound Healing Property Review of Siam Weed, Chromolaena odorata. Pharmacogn. Rev. 2017, 11, 35-38.

193. Ayyanar, M.; Ignacimuthu, S. Herbal medicines for wound healing among tribal people in Southern India: Ethnobotanical and scientific evidences. Int. J. Appl. Res. Nat. Prod. 2009, 2, 29-42.

194. Sivajothi, V.; Shruthi, D.S.; Sajini, R.J. Cytotoxic effect of Heliotropium indicum extracts on Hela cell lines. Int. J. Pharm. Pharm. Sci. 2015, 7, 412-414.

195. Chunthorng-Orn, J.; Dechayont, B.; Phuaklee, P.; Prajuabjinda, O.; Juckmeta, T.; Itharat, A. Cytotoxic, anti-inflammatory and antioxidant activities of Heliotropium indicum extracts. J. Med. Assoc. Thail. 2016, 99, 102-109.

196. Dash, G.K.; Abdullah, M.S. A review on Heliotropium indicum L. (Boraginaceae). Int. J. Pharm. Sci. Res. 2013, 4, 1253-1258.

197. Koffuor, G.A.; Boye, A.; Amoateng, P.; Ameyaw, E.O.; Abaitey, A.K. Investigating the site of action of an aqueous extract of Heliotropium indicum linn (Boraginaceae) on smooth muscles. Res. J. Pharmacol. 2012, 6, 12-19.

198. Sobiyi, O.K.; Ashafa, A.O.T. In vitro anthelmintic activity of Heliotropium indicum, Senna fistula and Spigelia anthelmia used as worm expeller in South West Nigeria. Bangladesh J. Pharmacol. 2015, 10, 417-422. [CrossRef]

199. Andujar, I.; Recio, M.; Giner, R.; Ríos, J. Traditional Chinese Medicine Remedy to Jury: The Pharmacological Basis for the Use of Shikonin as an Anticancer Therapy. Curr. Med. Chem. 2013, 20, 2892-2898. [CrossRef]

200. Sun, H.; Xu, H.; Zhang, A.; Wang, P.; Han, Y.; Wang, X. In vitro anticancer activity of acetylshikonin action against cervical cancer. Plant Sci. Today 2014, 1, 39-45. [CrossRef]

201. Sasaki, K.; Abe, H.; Yoshizaki, F. In vitro antifungal activity of naphthoquinone derivatives. Biol. Pharm. Bull. 2002, 25, 669-670. [CrossRef]

202. Deng, X.-L. Antiviral Agents from Traditional Chinese Medicines against Hepatitis B Virus. Ph.D. Thesis, Chinese University of Hong Kong, Hong Kong, China, 2003.

203. Aydin, A.A.; Zerbes, V.; Parlar, H.; Letzel, T. The medical plant butterbur (Petasites): Analytical and physiological (re)view. J. Pharm. Biomed. Anal. 2013, 75, 220-229. [CrossRef] 
204. D'Onofrio, F.; Raimo, S.; Spitaleri, D.; Casucci, G.; Bussone, G. Usefulness of nutraceuticals in migraine prophylaxis. Neurol. Sci. 2017, 38, 117-120. [CrossRef]

205. Avula, B.; Sagi, S.; Wang, Y.H.; Zweigenbaum, J.; Wang, M.; Khan, I.A. Characterization and screening of pyrrolizidine alkaloids and $\mathrm{N}$-oxides from botanicals and dietary supplements using UHPLC-high resolution mass spectrometry. Food Chem. 2018, 178, 136-148. [CrossRef]

206. Wang, D.; Huang, L.; Chen, S. Senecio scandens Buch.-Ham.: A review on its ethnopharmacology, phytochemistry, pharmacology, and toxicity. J. Ethnopharmacol. 2013, 149, 1-23. [CrossRef] [PubMed]

207. Waako, P.J.; Katuura, E.; Smith, P.; Folb, P. East African medicinal plants as a source of lead compounds for the development of new antimalarial drugs. Afr. J. Ecol. 2007, 45, 102-106. [CrossRef]

208. De Wet, H.; Ramulondi, M.; Ngcobo, Z.N. The use of indigenous medicine for the treatment of hypertension by a rural community in northern Maputaland, South Africa. South Afr. J. Bot. 2016, 103, 78-88. [CrossRef]

209. Hnatyszyn, O.; Moscatelli, V.; Garcia, J.; Rondina, R.; Costa, M.; Arranz, C.; Balaszczuk, A.; Ferraro, G.; Coussio, J.D. Argentinian plant extracts with relaxant effect on the smooth muscle of the corpus cavernosum of Guinea pig. Phytomedicine 2003, 10, 669-674. [CrossRef] [PubMed]

210. Pérez González, C.; Serrano Vega, R.; González-Chávez, M.; Zavala Sánchez, M.A.; Pérez Gutiérrez, S. Anti-inflammatory activity and composition of Senecio salignus Kunth. Biomed Res. Int. 2013, 1, 1-4. [CrossRef]

211. Liu, F.; $\mathrm{Ng}$, T.B. Antioxidative and free radical scavenging activities of selected medicinal herbs. Life Sci. 2000, 66, 725-735. [CrossRef]

212. Durre Shahwar Antioxidant potential of the extracts of Putranjiva roxburghii, Conyza bonariensis, Woodfordia fruiticosa and Senecio chrysanthemoids. Afr. J. Biotechnol. 2012, 11, 4288-4295.

213. Sharma, P.; Shah, G.C. Composition and antioxidant activity of Senecio nudicaulis Wall. ex DC. (Asteraceae): A medicinal plant growing wild in Himachal Pradesh, India. Nat. Prod. Res. 2015, 29, 883-886. [CrossRef]

214. Rojo, L.E.; Benites, J.; López, J.; Rojas, M.; Díaz, P.; Ordóñez, J.; Pastene, E. Antioxidant capacity and polyphenolic content of twelve traditionally used herbal medicinal infusions from the South American Andes. Bol. Latinoam. Caribe Plantas Med. Aromat. 2009, 8, 498-508.

215. Fortin, H.; Vigor, C.; Lohézic-Le Dévéhat, F.; Robin, V.; Le Bossé, B.; Boustie, J.; Amoros, M. In vitro antiviral activity of thirty-six plants from La Réunion Island. Fitoterapia 2002, 73, 346-350. [CrossRef]

216. Li,H.; Zhou, C.; Zhou, L.; Chen, Z.; Yang, L.; Bai, H.; Wu, X.; Peng, H.; Zhao, Y. In vitro antiviral activity of three enantiomeric sesquiterpene lactones from Senecio species against hepatitis B virus. Antivir. Chem. Chemother. 2005, 16, 277-288. [CrossRef] [PubMed]

217. Echiburú-Chau, C.; Alfaro-Lira, S.; Brown, N.; Salas, C.O.; Cuellar, M.; Santander, J.; Ogalde, J.P.; Rothhammer, F. The selective cytotoxicity elicited by phytochemical extract from Senecio graveolens (Asteraceae) on breast cancer cells is enhanced by hypoxia. Int. J. Oncol. 2014, 44, 1357-1364. [CrossRef] [PubMed]

218. Hong, Q.; Minter, D.E.; Franzblau, S.G.; Reinecke, M.G. Anti-tuberculosis compounds from two Bolivian medicinal plants, Senecio mathewsii and Usnea florida. Nat. Prod. Commun. 2008, 3, 1377-1384. [CrossRef]

219. Romo De Vivar, A.; Pérez, A.L.; Vidales, P.; Nieto, D.A.; Villaseñor, J.L. Pyrrolizidine alkaloids from Senecio jacalensis and Senecio callosus. Biochem. Syst. Ecol. 1996, 24, 175-176. [CrossRef]

220. Liddell, J.R.; Stermitz, F.R.; Lombardo De Barros, C.S. Pyrrolizidine alkaloids from Senecio oxyphyllus, a Brazilian poisonous plant. Biochem. Syst. Ecol. 1992, 20, 393. [CrossRef]

221. Craig, A.M.; Sheggeby, G.; Wicks, C. Large scale extraction of pyrrolizidine alkaloids from tansy ragwort (Senecio jacobaea). Vet. Hum. Toxicol. 1984, 26, 108-111.

222. Bestimmung von Pyrrolizidinalkaloiden (PA) in Pflanzenmaterial Mittels SPE-LC-MS/MS. Available online: https://www.bfr.bund.de/cm/343/bestimmung-von-pyrrolizidinalkaloiden.pdf (accessed on 27 February 2019).

223. Staiger, C. Comfrey root: From tradition to modern clinical trials. Wien. Med. Wochenschr. 2013, 163, 58-64. [CrossRef]

224. Frölich, C.; Ober, D.; Hartmann, T. Tissue distribution, core biosynthesis and diversification of pyrrolizidine alkaloids of the lycopsamine type in three Boraginaceae species. Phytochemistry 2007, 68, 1026-1037. [CrossRef]

225. Wu, Q.Z.; Zhao, D.X.; Xiang, J.; Zhang, M.; Zhang, C.F.; Xu, X.H. Antitussive, expectorant, and anti-inflammatory activities of four caffeoylquinic acids isolated from Tussilago farfara. Pharm. Biol. 2016, 54, 1117-1124. [CrossRef] 
226. Janovska, D.; Kubikova, K.; Kokoska, L. Screening for antimicrobial activity of some medicinal plants species of traditional Chinese medicine. Czech. J. Food Sci. 2003, 21, 107-110. [CrossRef]

227. Uzun, E.; Sariyar, G.; Adsersen, A.; Karakoc, B.; Ötük, G.; Oktayoglu, E.; Pirildar, S. Traditional medicine in Sakarya province (Turkey) and antimicrobial activities of selected species. J. Ethnopharmacol. 2004, 95, 287-296. [CrossRef]

228. Zhao, J.; Evangelopoulos, D.; Bhakta, S.; Gray, A.I.; Seidel, V. Antitubercular activity of Arctium lappa and Tussilago farfara extracts and constituents. J. Ethnopharmacol. 2014, 155, 796-800. [CrossRef]

229. Cho, J.; Kim, H.M.; Ryu, J.-H.; Jeong, Y.S.; Lee, Y.S.; Jin, C. Neuroprotective and antioxidant effects of the ethyl acetate fraction prepared from Tussilago farfara L. Biol. Pharm. Bull. 2005, 28, 455-460. [CrossRef] [PubMed]

230. Kim, M.R.; Lee, J.Y.; Lee, H.H.; Aryal, D.K.; Kim, Y.G.; Kim, S.K.; Woo, E.R.; Kang, K.W. Antioxidative effects of quercetin-glycosides isolated from the flower buds of Tussilago farfara L. Food Chem. Toxicol. 2006, 44, 1299-1307. [CrossRef] [PubMed]

(C) 2020 by the authors. Licensee MDPI, Basel, Switzerland. This article is an open access article distributed under the terms and conditions of the Creative Commons Attribution (CC BY) license (http://creativecommons.org/licenses/by/4.0/). 